\title{
Floristic and Vegetation Changes on a Small Mediterranean Island over the Last Century
}

\author{
Saverio Sciandrello ${ }^{1, *} * \mathbb{C}$, Salvatore Cambria ${ }^{1}$, Gianpietro Giusso del Galdo ${ }^{1}$, Riccardo Guarino ${ }^{2}(\mathbb{D}$, \\ Pietro Minissale ${ }^{1} \mathbb{D}$, Salvatore Pasta ${ }^{3}$, Gianmarco Tavilla ${ }^{1} \mathbb{D}$ and Antonia Cristaudo ${ }^{1} \mathbb{D}$ \\ 1 Department of Biological, Geological and Environmental Sciences, University of Catania, via A. Longo 19, \\ 95125 Catania, Italy; cambria_salvatore@yahoo.it (S.C.); g.giusso@unict.it (G.G.d.G.); \\ p.minissale@unict.it (P.M.); gianmarco.tavilla@phd.unict.it (G.T.); acristau@unict.it (A.C.) \\ 2 Department STEBICEF, University of Palermo, via Archirafi 38, 90123 Palermo, Italy; \\ riccardo.guarino@unipa.it \\ 3 Institute of Biosciences and BioResources (IBBR), National Research Council (CNR), Unit of Palermo, \\ Corso Calatafimi 414, 90129 Palermo, Italy; salvatore.pasta@ibbr.cnr.it \\ * Correspondence: s.sciandrello@unict.it
}

Citation: Sciandrello, S.; Cambria, S.; Giusso del Galdo, G.; Guarino, R.; Minissale, P.; Pasta, S.; Tavilla, G.; Cristaudo, A. Floristic and Vegetation Changes on a Small Mediterranean Island over the Last Century. Plants 2021, 10, 680. https://doi.org/ $10.3390 /$ plants 10040680

Academic Editor: Pablo Vargas

Received: 2 March 2021

Accepted: 28 March 2021

Published: 1 April 2021

Publisher's Note: MDPI stays neutral with regard to jurisdictional claims in published maps and institutional affiliations.

Copyright: (C) 2021 by the authors. Licensee MDPI, Basel, Switzerland. This article is an open access article distributed under the terms and conditions of the Creative Commons Attribution (CC BY) license (https:/ / creativecommons.org/licenses/by/ $4.0 /)$.

\begin{abstract}
A synthetic and updated overview about the vascular flora and vegetation of the Island of Capo Passero (SE-Sicily) is provided. These data issue from two series of field surveys-the first carried out between 1997 and 2000, and the second between 2005 and 2019 and mostly focused on refining and implementing vegetation data. The current islet's flora consists of 269 taxa, of which 149 (58\%) are annual plants. The Mediterranean species are largely prevailing, 108 (40\%) of which have a strictly Mediterranean biogeographical status. The comparison with a species list published in 1919 and updated in 1957 suggest that, despite the overall prevalence of anemochorous taxa, the vertebrate fauna represents an important vector for the plant colonization of the island, while the immigration of myrmechocorous taxa does not compensate the extinction rate. As many as 202 phytosociological relevés, 191 of which issue from original recent field surveys, enabled identifying 12 different plant communities. The comparison with a vegetation map published in 1965 suggests a strong reduction in dune habitats (2120 and 2210 according to EU 'Habitats' Directive 92/43), as well as a deep disruption in the succession typical of the local psammophilous vegetation series. In order to preserve rare, endangered and protected plant species (such as Aeluropus lagopoides, Cichorium spinosum, Limonium hyblaeum, L. syracusanum, Poterium spinosum, Senecio pygmaeus and Spergularia heldreichii) and to stop the ongoing habitat degradation, urgent and effective conservation measures should be adopted for this tiny, yet precious islet.
\end{abstract}

Keywords: landscape dynamics; turnover; nature conservation; diachronic analysis; vegetation; Mediterranean islets

\section{Introduction}

Although they represent a small part of the emerged lands, islands host a remarkable portion of the global biological richness [1]. Indeed, the isolation of these lands and their ecosystems has not only favoured the processes of evolutionary divergence and endemism, but also offered refuge to organisms that are threatened or have disappeared elsewhere.

Additionally, the small uninhabited islets offer an exceptional research field for life scientists because they represent both conservative and extremely simplified contexts [2-9]. As for the small circum-Sicilian islets, they represent sites of high conservation value for the occurrence of several endemic or rare vascular plant species [10,11]. In the past, many of them drove the interest of botanists, which have mainly investigated their vascular floras [12-27].

Among the circum-Sicilian islets, the Island of Capo Passero (SW-Sicily) stands out for having a prominent interest because, thanks to its easy accessibility, it has been targeted by numerous botanists. Its vascular flora was investigated for the first time during 
spring 1664 by the English botanist John Ray, who recorded more than 60 plants. Even if incomplete, Ray's list probably represents the first inventory of a small Mediterranean island and provides interesting information on the plants growing there more than 350 years ago $[28,29]$.

A far more complete plant species list, issuing from two visits carried out on the islet (1909 and 1917), was published long time after by Albo [30], with some additions 40 years later [31]. The Island of Capo Passero has been attractive to botanists not only for its flora but also for its landscape peculiarities. For instance, Albo [30] emphasized the remarkable integrity and extent of the local dwarf palm (Chamaerops humilis L.) community, defined in the same years as "the most beautiful dwarf-palm shrubland in Italy" [32]. The first vegetation surveys were carried out on the islet by Pirola $[33,34]$. During the following decades, many species new to Island of Capo Passero have been reported by Galletti [35] and by Camatta et al. [36].

In the last 25 years, the authors of the present contribution carried out two series of field surveys. The first one (from 1997 to 2000) enabled actualizing local flora and vegetation data, the second (from 2005 to 2019) was mostly focused on refining and implementing the vegetation dataset. With the exception of some information already published by Cristaudo and Maugeri [37] and Cristaudo and Margani [38], the data issuing from both campaigns are here presented for the first time. Main objective of this contribution are: (1) to provide an updated list of the local vascular flora, (2) to present a comprehensive syntaxonomic framework of the local plant communities, and (3) to perform a diachronic analysis of the flora and vegetation changes occurred during last 60 years and provide an explanation for them.

\section{Results and Discussion}

\subsection{The Vascular Flora: Traits Analysis and Taxa of Outstanding Interest}

The vascular plant species recorded from the Island of Capo Passero during the last century and their related traits are listed in alphabetical order in Appendix A.

Our field surveys enabled confirming the occurrence of 269 taxa belonging to 55 families. The families represented by more than 10 taxa were the following: Asteraceae (42 taxa), Poaceae (38 taxa), Fabaceae (29 taxa), Caryophyllaceae (14 taxa) and Apiaceae (11 taxa). Therophytes were the prevalent life form (149 taxa, i.e., 56\% of the whole flora), followed by hemicryptophytes $(64 ; 23 \%)$ and geophytes $(29 ; 11 \%)$, while the percentage of chamaephytes $(16 ; 6 \%)$ and (nano-)phanerophytes $(11 ; 4 \%)$ was very low (Figure 1$)$.
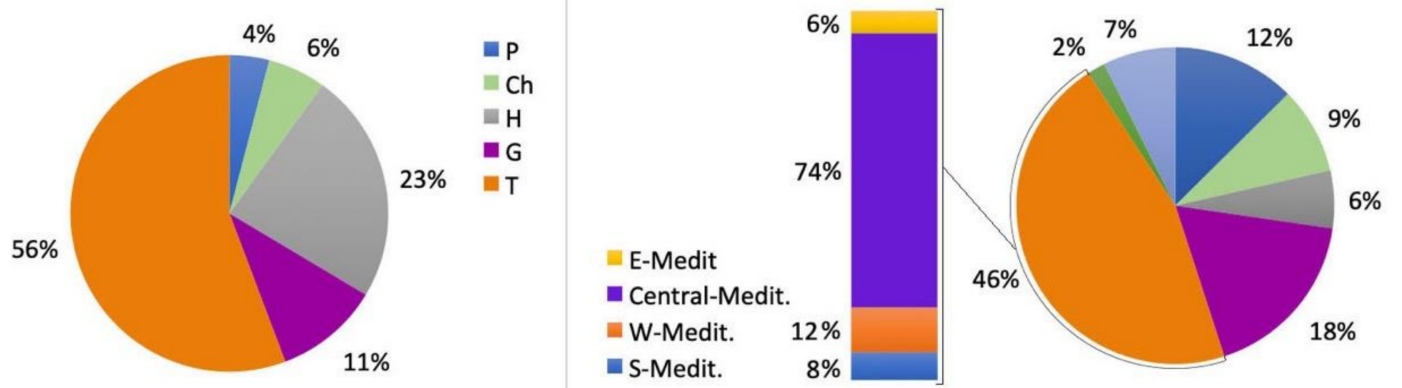

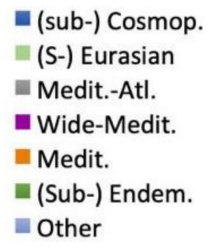

Figure 1. Life form (left) and biogeographical status (right) of the taxa recorded from the Island of Capo Passero in our survey (see Appendix A). Life form abbreviations: P, phanerophytes; Ch, chamaephytes; $\mathrm{H}$ hemicryptophytes; G, geophytes; $\mathrm{T}$, therophytes.

The Mediterranean chorotype was largely prevailing (124 taxa; 46\%). Relevant was also the presence of the wide-Mediterranean (48; 18\%) and (sub-)cosmopolitan taxa (34; $12 \%$ ). The endemic component included two taxa restricted to SE-Sicily, Limonium hyblaeum and L. syracusanum, one restricted to SE-Sicily, Lampedusa and the Maltese Islands, Senecio pygmaeus, and two restricted to Sicily and southern Italy, Crocus longiflorus and Echium italicum subsp. siculum. The alien component, lumped into the category "other", is really 
negligible, being represented by five species which do not show any invasive behaviour locally (see Appendix A for details).

The ecological fingerprint of the vascular flora of the Island of Capo Passero, based on the Ellenberg's indicator values [39], suggested the intense solar radiation and the summer drought stress as major environmental drivers on the island, along with a neutral soil reaction and a relative lack of nutrients (Figure 2).
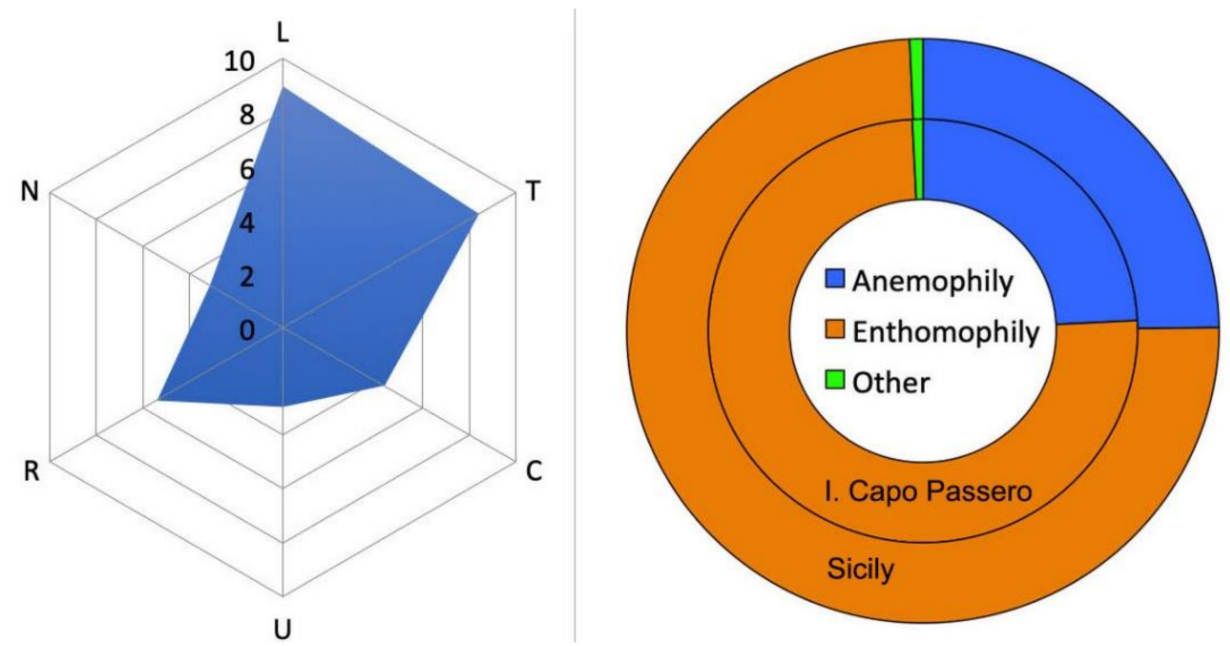

Figure 2. Ecogram of the vascular flora of the Island of Capo Passero (left) and target diagram (right) comparing the pollination strategies of the phanerogamic flora of Sicily with that of the Island of Capo Passero. Abbreviations: L-light conditions, T-temperature, C-continentality, U soil moisture, $\mathrm{R}$ soil reaction, $\mathrm{N}$-soil nutrients.

The pollination strategies of the flora of the Island of Capo Passero almost perfectly overlapped those of the whole Sicilian flora, characterized by a large prevalence of enthomophilous taxa (Figure 2). Similarly, no significant variations were observed in the seed dispersal strategies, apart from endozoochory, that is proportionally more represented in the flora of Sicily (Figure 3, first two columns).
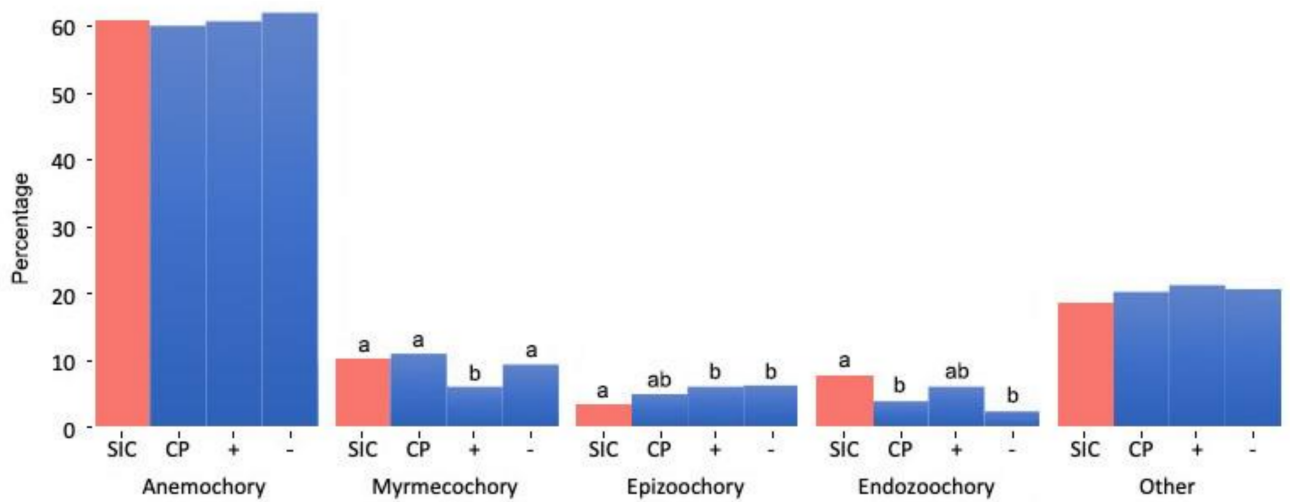

Figure 3. Seed dispersal strategies of the phanerogamic flora of Sicily (SIC) with that of the Island of Capo Passero (CP). The bar "+" refers to the species recorded in the present survey but not observed by Albo $(1919,1957) ; "$-" refers to the species recorded by Albo (l.c.) but not observed by us. Different letters indicate significant differences $(p<0.05)$.

The floristic differences with respect to the Albo's checklists $[30,31]$ suggested that, despite the overall prevalence of anemochorous taxa, the vertebrate fauna represents an important vector for the plant colonization of the island and that epizoochorous plants have more chances to survive than endozoochorous. Additionally, the immigration of myrmechocorous taxa does not compensate the extinction rate (Figure 3, first three columns). 
The flora of the Island of Capo Passero hosts several taxa of high phytogeographic interest. The most interesting ones are briefly commented in the following paragraphs.

\subsubsection{Aeluropus lagopoides (L.) Trin. ex Thwaites}

This salt-tolerant geophyte usually grows in the gaps of chenopod scrub. Its distribution range includes the Mediterranean Islands, the Sahara and the Indian Subcontinent. Once widespread in Sicily, due to anthropogenic disturbance it currently occurs in few saltmarshes of western and southeastern Sicily. It features among the species assigned to Least Concern (LC) category according to IUCN criteria [40].

\subsubsection{Cichorium spinosum $\mathrm{L}$.}

In Italy, this species is restricted to the SE-Sicilian coasts [31,41], which actually host the north-westernmost isolated population of this chamaephytic plant, quite common from sea level up to more than $1300 \mathrm{~m}$ a.s.l. in the East Mediterranean countries, but also widespread in Maltese Islands [42]. In the Island of Capo Passero, C. spinosum is localized in small areas along the rocky coast. Orsenigo et al. [40] reports this species as Endagered (EN) according to IUCN criteria.

\subsubsection{Limonium hyblaeum Brullo}

This salt-tolerant hemicryptophyte is considered to be endemic to SE-Sicily, where it is found only between Scoglitti and Capo Passero [43-46]. Quite surprisingly, it also occurs on the coastal rocky shores of Contrada Faraglione on the island Favignana (western Sicily), where it was already reported by Brullo [45] and was confirmed by S. Pasta and L. Scuderi (October 2004). As for the Island of Capo Passero, one single small population, represented by tiny individuals, was observed growing near the Spanish fortress. Although Orsenigo et al. [47] assigned the IUCN category Least Concern (LC) to this species, during recent times its extent of occurrence is rapidly shrinking, as the species is currently threatened with urban sprawl in most of its growing sites.

\subsubsection{Limonium syracusanum Brullo}

This chamaephyte is endemic to SE-Sicily $[44,45]$. More in detail, it is only found on the rocky cliffs along the Ionian coasts, between Penisola della Maddalena and Vendicari [41, $43,48]$. Never observed before on the islet, local population counts only a few individuals, localized in the extreme southern tip of the island. Orsenigo et al. [47] included this species among the Least Concern (LC).

\subsubsection{Poterium spinosum $\mathrm{L}$.}

In Italy, this thorny shrub occurs in Calabria, Apulia and in one single locality of Sardinia [49], while SE Sicily hosts its main population, ranging from the sea level up to $600 \mathrm{~m}$ a.s.l.. Recently, Orsenigo et al. [40] confirmed the status Endangered (EN) for the Italian territory.

\subsubsection{Senecio pygmaeus DC.}

This therophyte is reported to be endemic to SE-Sicily, Maltese Archipelago and Lampedusa, growing near the coast, mostly in shallow soil pockets or along the sides of seasonal rock pools. Conti et al. [50] reported it as Endagered (EN) at the regional scale.

\subsubsection{Spergularia heldreichii E. Simon \& P. Monnier}

The Island of Capo Passero hosts the only known population of this tiny therophyte in the whole Sicilian territory [38]. This salt-tolerant plant species, with a Mediterranean distribution, grows along the rocky coast, on small pools with sandy soil rich in salt, and subject to temporary flooding. Currently, no risk assessment has been carried out for this species. 


\subsection{Species Turnover, Population Trends and Landscape Evolution}

Even if the list compiled by Albo presented a few identification pending issues (see notes in Appendix A for further details), the long time elapsed since his investigation on the Island of Capo Passero and the most recent ones raises some interesting considerations on the extent and direction of local species turnover and induced the authors to try to correlate these trends with local landscape dynamics. Several psammophilous species reported by Albo [30] have not been found anymore, such as Achillea maritima, Eryngium maritimum, Echinophora spinosa. This fact, together with the negative trend of some other coastal plants, such as Limonium hyblaeum and Calamagrostis arenaria subsp. arundinacea (=Ammophila arenaria) point out the severe effect of current disturbances (mostly linked to the seagull colony and seasonal tourism), to which have to be added also the sea currents and the wave motion that, in recent years, have determined the erosion of the sandy coast.

As already pointed out by Bergmeier and Dimopoulos [51], when the time lapse between floristic inventories is too large, like in our case, the available lists are often unable to 'capture' the ups and downs of local plant metapopulations. The risk of observation gaps is real: on the one hand, during the 30 years after the last census of Albo [31] as much as 48 taxa new to the islet have been recorded by Pirola [33] (8 additions), Galletti [35] (16 additions) and by Camatta et al. [36] (24 additions). On the other hand, many of these 'new entries' seem to have disappeared once again, as they have not been confirmed neither during the campaign carried out between 1997 and 2000 nor during last surveys (see Appendix A).

According to one of the key assumptions of island biogeography [52], colonization chances are higher-and consequently species turnover is more intense-on the small islets which are very close to large "species sources": this is the case of the tiny Island of Capo Passero, only 300 metres from the largest and plant species-richest island of the Mediterranean. Hence, it is not surprising if a relevant proportion of the taxa observed by Albo does not occur anymore. For the same reason, several species found for the first time by Cristaudo and Maugeri [37] (e.g., Hypericum triquetrifolium, Lemna minor, Vicia bithynica) have not been confirmed during the last survey, when some other taxa (e.g., Arenaria serpyllifolia, Cachrys pungens, Plantago afra, Spergularia rubra and Vicia villosa) were recorded for the first time (see Appendix A).

\subsection{Current Vegetation Units}

The cluster analysis of all vegetation relevés shows two main branches and 12 groups of plots belonging to 10 phytosociological classes (Figure 4, Appendices B and C).

The first branch is characterized by scrub vegetation (cluster A1) and psammophilous communities together with the annual herbaceous communities (cluster A2); the second one (cluster B) includes the litho-halophilous vegetation linked to rocky coasts. The tallest vegetation found in the island is a maquis dominated by Chamaerops humilis and Pistacia lentiscus, referred to Pistacio lentisci-Chamaeropetum humilis (cluster 1, Table A2), which occurs in many other coastal sites of North-Western and South-Eastern Sicily [12,53-55]. This maquis is often replaced by a phrygana-like shrubland dominated by the thorny cushions of Poterium spinosum on dry rocky stands with a shallow layer of soil, often representing a degradation serial stage of the coastal maquis. According to Minissale et al. [48], this community may be referred to the association Chamaeropo-Sarcopoterietum spinosi (cluster 2, Table A2). The most degraded stage of the vegetation in the inner areas is represented by a community dominated by Stipellula capensis and Asteriscus aquaticus belonging to Stipo-Bupleuretalia semicompositi order (cluster 3, Table A3), which is linked to uncultivated fields. Along the limestone rocky coast, in the small depressions covered by a thin silty-sandy layer, an annual halo-nitrophilous vegetation grows referable to Parapholido incurvae-Catapodietum balearici, often mixed with halophilous perennial species, as Limonium sinuatum and Limonium virgatum, and some annual plants of the class Stipo-Trachynietea distachyae (cluster 4, Table A2). Psammophilous vegetation only occurs in the few dune remnants near the southwestern shore of the islet. Across the landward gradient, the first 
community is the Salsolo-Cakiletum maritimae (cluster 7, Table A4), which forms the first vegetation belt along the shoreline, colonizing the sandy surfaces subject to accumulation of organic matter stranded during storm surges. This species-poor community is formed by late-flowering, scattered therophytes, namely Cakile maritima and Salsola tragus. The coastal erosion and strong winds induced a loss of the dunal vegetation dominated by Calamagrostis arenaria subsp. arundinacea (Ammophiletea), which normally occurs on well-developed shifting dunes. The floristic remnants include other psammophytes, such as Pancratium maritimum, Scolymus hispanicus and Euphorbia paralias (cluster 6, Table A4). Probably also because of the disappearance of Thynopyrum junceum, the latter species tends to become dominant on the embryonic dunes closer to the sea. Inwards, the retrodunal sand hosts a community dominated by Centaurea sphaerocephala, Ononis natrix subsp. ramosissima and Euphorbia terracina. This plant community can be referred to the Centaureo sphaerocephalae-Ononidetum ramosissimae (cluster 5, Table A4), growing on relatively stable and compact sandy soils [56]. The gaps among the above-mentioned perennial herbs and shrubs are covered by ephemeral psammophilous swards dominated by Silene nicaensis and Senecio coronopifolius belonging to Vulpietalia order. However, most of the island's coasts are charaterized by rock outcrops, colonized by communities belonging to the class Crithmo-Staticetea. Among these, the most widespread is the Crithmo maritimi-Limonietum virgati (cluster 10, Table A5), which is dominated by Limonium virgatum and Crithmum maritimum, and few other species, such as L. sinuatum and Cichorium spinosum. Conversely, the Limonietum hyblaei, already reported for the adjacent coast by Bartolo et al. [41], covers a very restricted area of the island (cluster 8, Table A5). These communities are often replaced by nuclei with Limonium virgatum and L. sinuatum, as a consequence of the anthropogenic disturbance. The brackish rock pools amidst the Crithmo-Staticetea vegetation and the seasonally inundated sediments behind the cliffs are home to a vegetation characterized by Arthrocaulon meridionalis, a succulent chenopod scrub usually linked to seasonally inundated salt marshes, and Limonium virgatum. This vegetation (cluster 11, Table A6) is quite similar to the Limonio virgati-Arthrocnemetum macrostachyi, an association belonging to the class Salicornietea fruticosae, described by Biondi et al. [57] from southern Apulia and already reported for Sicily by Minissale and Sciandrello [20]. Furthermore, on the island, in the hyper-nitrified areas, rarely subject to submersion, a vegetation dominated by Suaeda vera grows, with few other halophilous species, such as Halimione portulacoides, Arthrocaulon meridionalis, Aeluropus lagopoides, Limonium virgatum (cluster 12, Table A6). This halo-subnitrophilous vegetation is referable to Halimiono portulacoidis-Suaedetum verae, an association belonging to Suaedion verae, alliance of Salicornietea fruticosae [58]. The thin layer of sediments accumulating on limestones with horizontal attitude, intensively subject to seabird droppings and to human seasonal trampling, are colonized by a halo-nitrophilous annual community dominated by Mesembryanthemum nodiflorum and Beta maritima, belonging to Spergulario bocconei-Mesembryanthemetum nodiflori (cluster 9, Table A5), which usually forms a dense carpet covering large surfaces. In addition, to the plant communities described above, some other monophytic or floristically poor vegetation units have been observed in the island. In particular, the small temporary basins amidst the clearings of shrub vegetation are colonized by an ephemeral vegetation with Polypogon subspathaceus, while the coastal rocky crevices are characterized by an annual sub-halophilous community dominated by Senecio pygmaeus. Inland disturbed stands, with slightly humid soils, are colonized by Arundo donax, probably introduced on the island because its stems were, until a recent past, a precious material for construction, basketry and stakeing. Inland sandy soils, which were cultivated in the past, are colonized by Saccharum biflorum, probably also introduced by man as a windbreak. Finally, the banks of a small artificial basin for rainwater collection are colonized by Typha domingensis. 


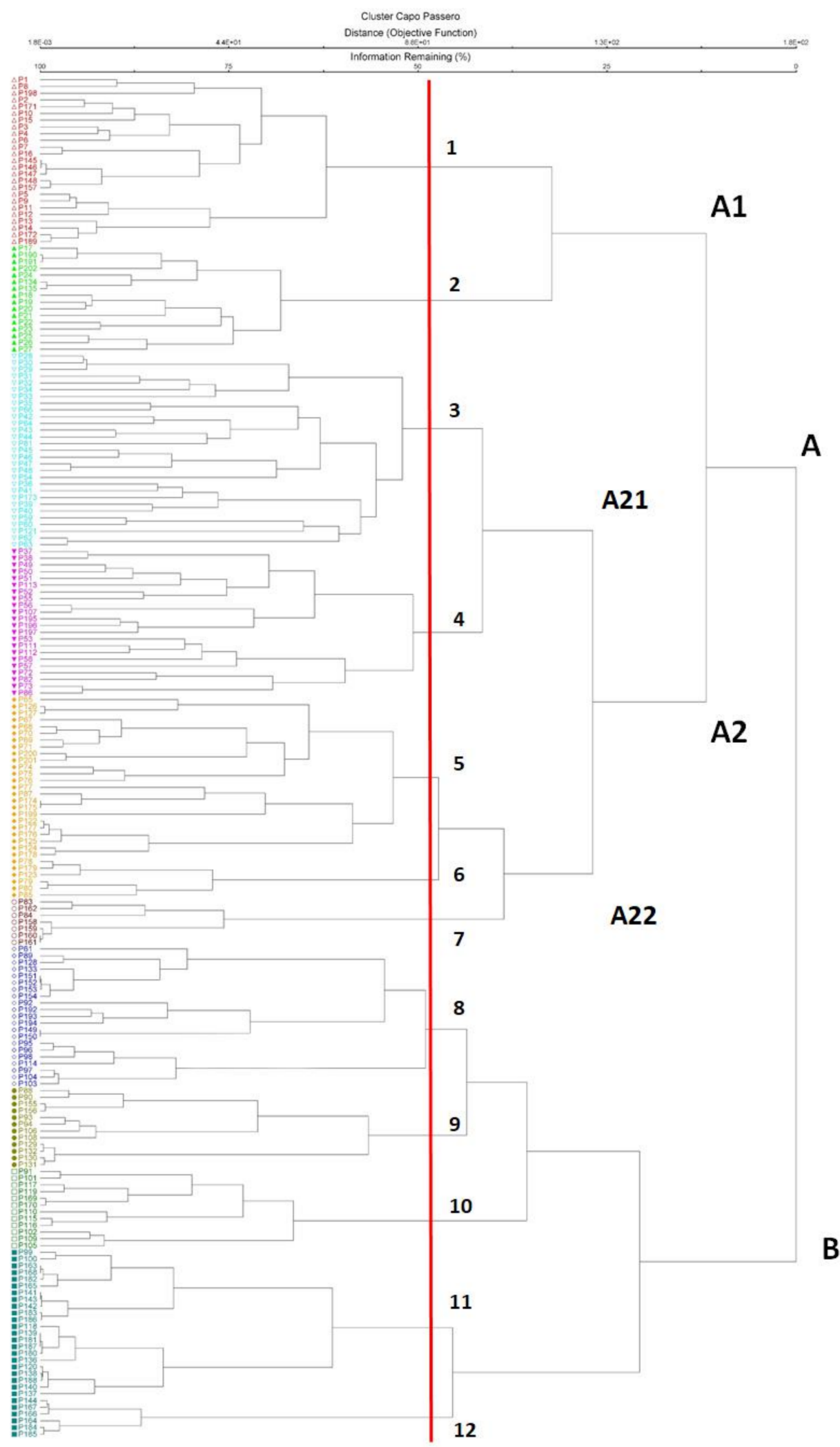

Figure 4. Cluster analysis of the surveyed plant communites: 1. Pistacio lentisci-Chamaeropetum humilis; 2 . Chamaeropo humilis-Sarcopoterietum spinosi; 3. Stipellula capensis and Asteriscus aquaticus community; 4. Parapholido incurvae-Catapodietum balearici; 5. Centaureo sphaerocephalae-Ononidetum ramosissimae; 6. Medicagini marinae-Ammophiletum australis; 7. SalsoloCakiletum maritimae; 8. Limonietum hyblaei; 9. Spergulario bocconei-Mesembryanthemetum nodiflori; 10. Crithmo maritimiLimonietum virgati; 11. Limonio virgati-Arthrocnemetum macrostachyi; 12. Halimiono portulacoidis-Suaedetum verae. 


\subsection{Changes Affecting Local Vegetation Patterns over Last Ha Century}

Interesting clues on the recent evolution of the landscape are given by the comparison between the vegetation map of Pirola [34] with a new one based on aerial photographs dating back to 2019 (Table 1, Figure 5).
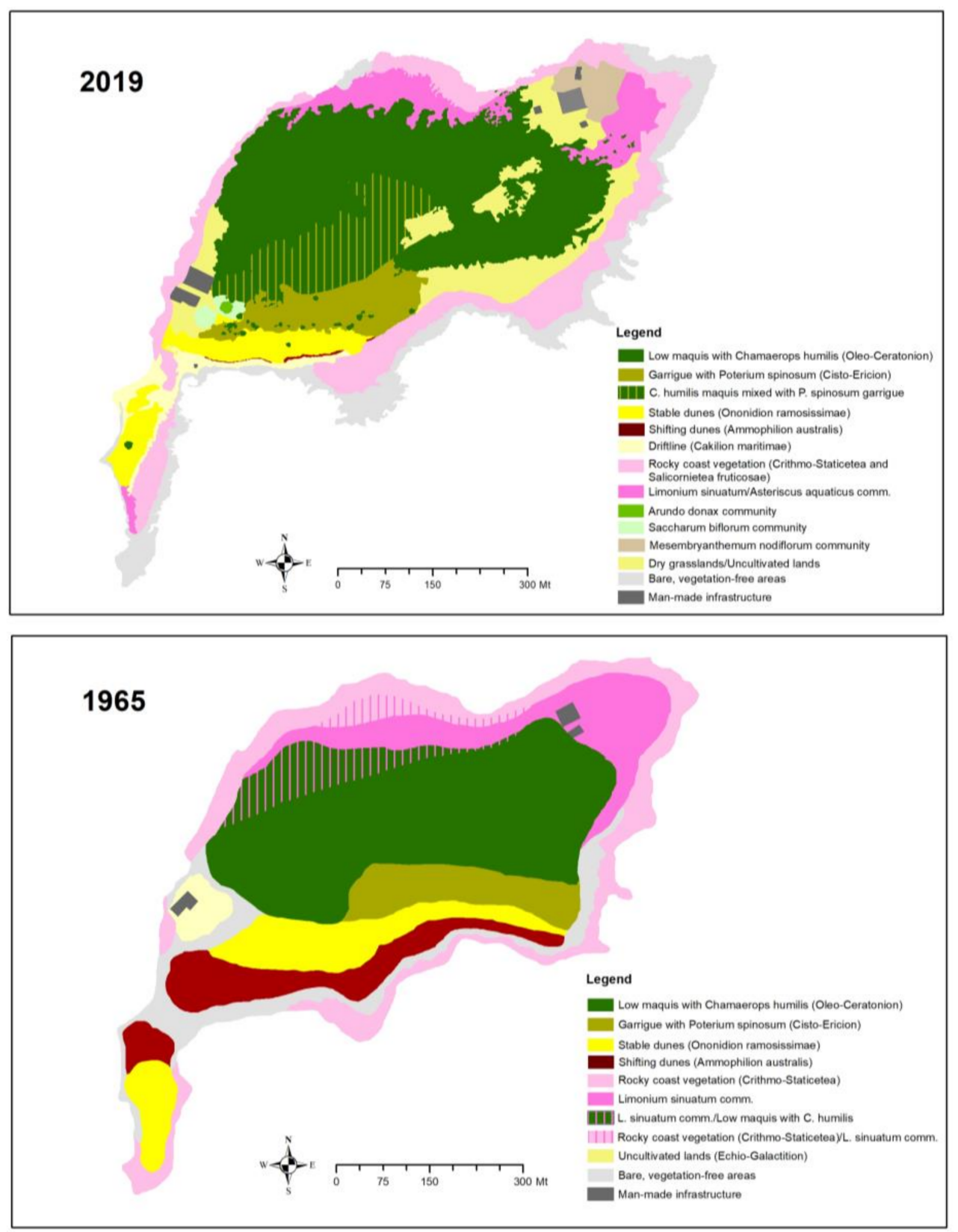

Figure 5. Comparison between the vegetation map published by Pirola (1965) and the one produced by the authors combining the interpretation of recent aerial photos (2019) and field surveys. The list of the plant communities is shown in the legend included in each map. The corresponding habitats (according to European Directive 92/43 CEE) for each plant communities are listed in Table 1.

Thanks to repeated cross-checks supported by field surveys, the photointerpretation of the aerial photos enabled identifying 12 vegetation types, 10 of which represent habitats of community interest according to the EU 'Habitats' Directive 92/43 (Figures A1 and A2).

The comparison of the two maps shows no significant differences in the area occupied by the vegetation. However, some variation in the area of occupancy of some vegetation units has been detected (Table 1). More in detail, the data show a strong shrinking of the vegetation of shifting dunes (Medicagini marinae-Ammophiletum arenarii) which decreased 
from 3 ha $(8.7 \%)$ in 1965 to 0.05 ha $(0.1 \%)$ in 2019, as well as of the Ononis ramosissima community (Centaureo-Ononidetum ramosissimae), which decreased from 3.6 ha $(10 \%)$ to $1.8(5.0 \%)$ ha. The cover of the most common plant community of the island, i.e., the dwarf maquis with Chamaerops humilis, has undergone a slight reduction, from 12.9 ha (36.0\%) to 11.0 ha $(31.0 \%)$. Inversely, the Poterium spinosum garrigue, together with the Chamaerops humilis maquis mixed with Poterium spinosum garrigue, increased from 2.4 ha $(6.7 \%)$ to 5 ha $(14.3 \%)$, as well as the dry grasslands (Stipo-Trachynietea distachyae) from $0.6 \mathrm{ha}(1.7 \%)$ to 3.5 ha $(10 \%)$.

The observed strong reduction in the dune system has been recorded in many other places along the Mediterranean coast [59-63]. These results highlight that human pressure directly and indirectly triggered the disruption of coastal dune systems, hugely affecting both the structure and the function of the local psammophilous plant communities. Therefore, the study case of Capo Passero Island, despite the modest size of the surveyed area, is a very representative example of how, within a few decades, seasonal trampling by tourists can destroy a dune system with direct negative consequences on the species and the communites/habitats linked to sandy shores. For the same reasons, some psammophilous species, recorded by Albo [30], such as Achillea maritima, Eryngium maritimum and Echinophora spinosa, have totally disappeared. This is in contrast to the conditions observed by Pirola [33], who depicted a vegetation transect (North-South section) indicating a well-preserved dune system in the southern part of the island.

Table 1. Comparison of the surface covered by the different vegetation units/habitats based on the vegetation map of Pirola [34] and authors' recent vegetation map (2019).

\begin{tabular}{|c|c|c|c|c|c|}
\hline & & 1950 & & 2019 & \\
\hline Vegetation & Habitat & ha & $\%$ & ha & $\%$ \\
\hline $\begin{array}{l}\text { Stable dunes (Ononidion } \\
\text { ramosissimae) }\end{array}$ & 2210 & 3.6 & 10.0 & 1.8 & 5.0 \\
\hline $\begin{array}{l}\text { Shifting dunes (Ammophilion } \\
\text { australis) }\end{array}$ & 2120 & 3.1 & 8.7 & 0.05 & 0.1 \\
\hline $\begin{array}{l}\text { Driftline (Cakilion maritimae) } \\
\text { Low maquis with }\end{array}$ & 1210 & - & - & 0.88 & 2.5 \\
\hline $\begin{array}{l}\text { Chamaerops humilis } \\
\text { (Oleo-Ceratonion) } \\
\text { Chamaerops humilis maquis }\end{array}$ & 5330 & 12.9 & 36.0 & 10.89 & 30.7 \\
\hline $\begin{array}{l}\text { mixed with Poterium } \\
\text { spinosum garrigue }\end{array}$ & - & - & - & 3.05 & 8.6 \\
\hline $\begin{array}{l}\text { Garrigue with Poterium } \\
\text { spinosum (Cisto-Ericion) }\end{array}$ & 5420 & 2.4 & 6.7 & 2.04 & 5.8 \\
\hline $\begin{array}{l}\text { Limonium sinuatum } \\
\text { community (incl. } \\
\text { Parapholido-Catapodietum } \\
\text { balearici) }\end{array}$ & 1240 & 4.5 & 12.6 & 2.33 & 6.6 \\
\hline $\begin{array}{l}\text { Rocky coast vegetation } \\
\text { (Crithmo-Limonietea and } \\
\text { Salicornietea fruticosae) }\end{array}$ & $1240,1310,1420$ & 5.6 & 15.6 & 5.82 & 16.4 \\
\hline $\begin{array}{l}\text { Mesembryanthemum } \\
\text { nodiflorum/Beta maritima } \\
\text { community }\end{array}$ & 1310 & - & - & 0.64 & 1.8 \\
\hline $\begin{array}{l}\text { Dry grasslands } \\
\text { (Stipo-Trachynietea distachyae) }\end{array}$ & 6220 & 0.6 & 1.7 & 3.53 & 10.0 \\
\hline $\begin{array}{l}\text { Saccharum biflorum } \\
\text { community }\end{array}$ & - & - & - & 0.19 & 0.5 \\
\hline Arundo donax community & - & - & - & 0.03 & 0.1 \\
\hline Bare, vegetation-free areas & - & 3.1 & 8.7 & 3.85 & 10.9 \\
\hline \multirow[t]{2}{*}{ Man-made infrastructure } & - & - & - & 0.39 & 1.0 \\
\hline & & 35.8 & & 35.49 & \\
\hline
\end{tabular}




\section{Materials and Methods}

\subsection{Study Area}

The Island of Capo Passero (latitude: $36^{\circ} 41^{\prime} 13^{\prime \prime} \mathrm{N}$; longitude: $15^{\circ} 08^{\prime} 56^{\prime \prime} \mathrm{E}$ ) has a surface of less than 36 ha and is located in front of the little town of Portopalo di Capo Passero, which corresponds to the south-easternmost corner of Sicily. The highest point of the island is $21 \mathrm{~m}$. a.s.l., and currently hosts a lighthouse (Figure 6).

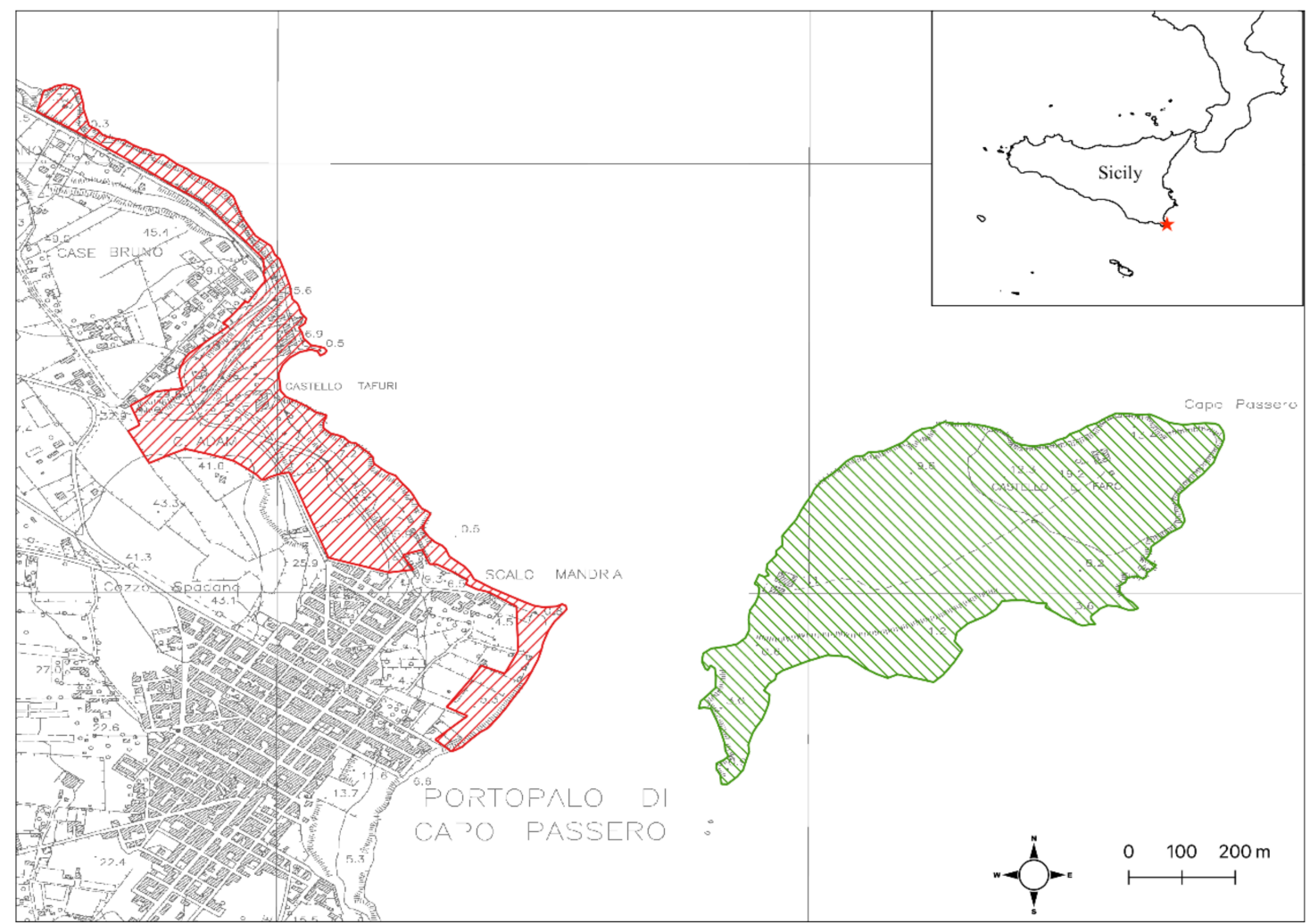

Figure 6. Proposed enlargement on the mainland of the boundaries of the SAC ITA090001 "Isola di Capo Passero".

Despite its small size, the islet is characterized by many different types of sediments and rock outcrops [64,65]. From the most recent to the oldest one, these are: (1) recent sands and coastal dunes (Holocene), (2) limestones with Nummulites (Eocene) in the eastern part of the islet, (3) calcirudites with Rudistae (Upper Cretaceous) on northern sea cliffs and (4) base-rich vulcanites (Upper Cretaceous) along the eastern side.

The topography of the sea channel that separates the islet from Capo Passero, today c. $2.5 \mathrm{~m}$ in depth and $300 \mathrm{~m}$ in width, has been subject to continuous changes due to intense marine currents [66]. A long list of reports made by military engineers, maps, drawings, geographic treatises, sailor books testifie complex and long-lasting alternation of phases of closing and opening of this channel, partly driven by sea currents. After being isolated for about two centuries, around the mid 18th century the Island of Capo Passero was connected to the mainland by a thick sandy strip. Since then, the islet has been uninterruptedly separated from Sicily, as confirmed by numerous sources [29].

In order to prevent the incursions of pirates and to protect the south-eastern Sicilian coasts against them, the Spanish Government decided to build a fortress on the islet, whose construction was finished in 1635 [67]. Until mid 20th century, the islet was frequently visited by fishermen and people collecting the leaves of dwarf palms, whose fibers were used to produce several items (baskets, fans, hats, ropes, etc.). Nowadays, the Island of Capo Passero is uninhabited but it is home to a very large colony of yellow-legged seagulls (Larus michahellis Naumann), which induced a sharp increase in soil nitrogen content, significantly modifying local flora and vegetation as elsewhere in the Mediterranean [13]. 
Local climate is typically Mediterranean; based on the data from the nearby thermopluviometric station of Cozzo Spadaro (just $2.5 \mathrm{~km}$ from the study area), the mean annual temperature is $18.5^{\circ} \mathrm{C}$, while the mean annual precipitation, concentrated over the autumn and winter seasons, is $381 \mathrm{~mm}$. According to the bioclimatic classification proposed by Rivas-Martiínez et al. [68-70], the investigated territory should be referred to the Mediterranean pluviseasonal oceanic bioclimate, with low thermomediterranean thermotype and dry ombrotype [71].

\subsection{Data Sets and Data Processing}

The collected plant specimens, were pressed in a plant press, dried on a plant dryer and stored in the Herbarium of the University of Catania (CAT). Specimens were identified following the second edition of the Flora d'Italia [72-75]. The floras by Fiori and Paoletti [76] and Fiori [77] were consulted as well, to ensure the best possibile interpretation of the plant names adopted in the lists published by Albo [30,31].

The family and the scientific name according to the Portal to the Flora of Italy [78] were assigned to each taxon, along with the following traits, extracted from the second edition of Flora d'Italia [72-75]: life form, chorotype, Ellenberg indicator values, pollination and seed dispersal strategies. The Pearson's $\chi 2$ test was used to compare some of the traits with those of the Sicilian flora and to get some clues on the variations occurred between the Albo floristic surveys [30,31] and the current vascular flora of the Island of Capo Passero. Statistical analyses were performed using R 4.0.3 [79] and the ggplot2 package [80] for data visualization.

The vegetation was sampled according to the phytosociological method [81]. The total amount of the vegetation data consisted of 202 phytosociological relevés, 191 of them issuing from recent field surveys carried out by the authors and 11 taken from literature [33]. For the numerical vegetation classification, the original Braun-Blanquet's sampling scale was transformed into ordinal scale according to van der Maarel [82] and a hierarchical clustering was performed by means of the PC-ORD 6 software. Clusters were interpreted basing on the syntaxonomic scheme by Mucina et al. [83] and other phytosociological papers from Sicily [10]. The detected vegetation units were then correlated to habitats of community interest following the Italian Interpretation Manual for the Habitats of Directive 92/43/EEC [84].

The current area of occupancy and distribution of the vegetation units was mapped using ArcGis 10.6 (ESRI Inc., Redlands, CA, USA). In order to perform a diachronic comparison between the past [34] and the current vegetation patterns, the interpretation of aerial images taken in 2019 (source: Google Earth) was validated by means of repeated field surveys.

\section{Conclusions}

This study has shown how the islet of Capo Passero has great floristic peculiarities and at the same time considerable vulnerability that can cause extinctions/decline of populations and reduction/alterations of habitats under stress. For this reason, it is important to plan and implement targeted conservation actions similar to what has been proposed for other small Mediterranean islands [4,85]. Already 50 years ago, considering the botanical interest of the Island of Capo Passero, Pirola [86] recommended its strict protection. The "Isola di Capo Passero" nature reserve was established on 16 May 1995 by decree of the Sicilian Regional Government. However, in 1998, after a long legal dispute following an appeal against the reserve made by the private owner of the island, the TAR (Regional Administrative Tribunal) canceled the protected area. Fortunately, the conservation measures of the Habitats Directive (EU 92/43) have allowed so far guaranteeing lasting protection of the island's naturalistic values. In fact, after the SCI proposal dating back to 1995 (ITA090001 "Isola di Capo Passero"), this Natura 2000 site was promoted as a Special Conservation Area (SAC) in 2017. Unfortunately, the lack of an encharged management body for this Natura 2000 site does not allow the implementation of active 
conservation and management policies (e.g., the regulation of visitors' access by creating of dedicated paths for seasonal tourists, who represent a serious threat for all the coastal habitats - especially 1210, 2120 and 2210-due to trampling and other kinds of disturbance, the control/eradication of the few occurring alien vascular plant species. This is a problem in common with all the Sicilian Natura 2000 sites which do not fall within the protected areas whose management is regulated by regional laws (e.g., nature reserves or regional parks) and is perfomed by public bodies and private NGOs.

The peculiar interest of this site for botanists is well documented since centuries (Pasta, submitted) and its paramount importance until present times its confirmed by recent inclusion among the Italian Important Plant Areas (IPA SIC17) according to Blasi et al. [87]. Moreover, the island and the nearby coast have an exceptional geological and paleontological interest, highlighted since the mid 19th century, for its fossil-rich (rudists, corals) outcropping limestones dating back to Cretaceous [64]. The historical and cultural sites by the island's castle and the Roman remains on the adjacent coast are no less important [88]. Unfortunately, all these natural and historical-cultural values are not protected adequately by local institutions, which instead have recently promoted some actions aiming at consolidating the rocky coast with concrete, damaging the coastal communities of the mainland promontory and deliberately introducing highly invasive alien plants such as Carpobrotus spp. This plant should be eradicated or monitored to avoid its introduction on the islet. Therefore, the authors suggest extending the limits of the SAC, so to include the Cichorium spinosum populations located in the promontory of Capo Passero (Figure 6). This regionally rare and highly localized species characterizes two different habitats of community interest, i.e., the "Vegetated sea cliffs of the Mediterranean coasts with endemic spp." (Habitat code: 1240) and the "Sarcopoterium spinosum phryganas" (Habitat code: 5420). The enlargement of the Natura 2000 site, the designation of a qualified management body and the acquisition of the island as public ownership could guarantee a better management of this precious territory and the preservation not only of its naturalistic values but also the cultural heritage as a whole which originated, as in other Mediterranean sites, from with the harmonious balance between those values [89]. Although much still needs to be done, our map of plant communities (Figure 5) is a solid basis for the management and monitoring of the habitats to be protected over time.

This paper is addressed to all who believe that the site of Capo Passero deserves to be adequately managed and preserved, so that future generations will continue to appreciate its natural highlights, studied, described and appreciated since centuries by scientists, poets, historians, painters, travellers and geographers from all over Europe.

Author Contributions: S.S. conceived the project and organized the research group and developed the first theoretical framework; S.S., A.C., and P.M. carried out the field work; S.S., S.P., R.G., and A.C. contributed to setting the theoretical framework and data processing; S.S., G.G.d.G., S.P., G.T., and S.C. prepared and revised the data; S.S., R.G., and G.T. processed the data and prepared the graphical outputs; S.S., G.T., S.C., and A.C. prepared the first draft of the manuscript, with substantial inputs from S.P. and R.G.; A.C. funding acquisition. All authors have read and agreed to the published version of the manuscript.

Funding: This work was financially supported by the SiMaSeed Project "Protecting biodiversity in Sicily Malta Natura 2000 sites through Seed Banks and population reinforcement." Programme INTERREG V-A Italia-Malta 2014-2020. Priority Axis III, Specific Objective 3.1, Project code C1-3.1-16.

Data Availability Statement: All data presented in the manuscript are available in the form of tables and figures in the manuscript.

Acknowledgments: We thank the INTERREG V-A Italia-Malta 2014-2020 programme for supporting this study on the SAC ITA090001 'Isola di Capo Passero', as a very important site of the Natura 2000 Network. The study allowed to highlight several biodiversity values of both plants and habitats of community interest the site shares with the Maltese Islands.

Conflicts of Interest: The authors declare no conflict of interest. 


\section{Appendix A}

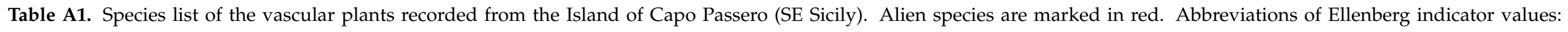

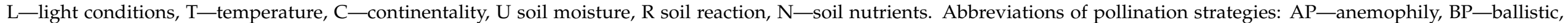

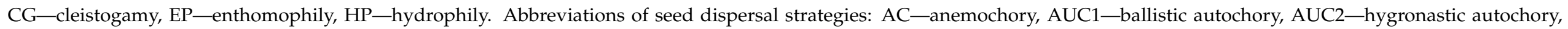
BC—barochory, HC—hydrochory, ZC1—epizoochory, ZC2—endozoochory, and ZC3—myrmecochory.

\begin{tabular}{|c|c|c|c|c|c|c|c|c|c|c|c|c|c|c|c|c|c|c|}
\hline $\mathbf{N}^{\circ}$ & Species & Family & Life Form & Chorotype & $\begin{array}{l}\text { This } \\
\text { Paper }\end{array}$ & $\begin{array}{c}\text { Albo } \\
\text { (1919; } \\
\text { 1957) * }\end{array}$ & $\begin{array}{l}\text { Pirola } \\
\text { (1959) }\end{array}$ & $\begin{array}{l}\text { Galletti } \\
\text { (1988) }\end{array}$ & $\begin{array}{l}\text { Camatta } \\
\text { et al. } \\
(1990) * *\end{array}$ & $\begin{array}{l}\text { Cristaudo } \\
\text { and } \\
\text { Maugeri } \\
(2005)\end{array}$ & $\mathbf{L}$ & $\mathrm{T}$ & C & $\mathrm{U}$ & $\mathbf{R}$ & $\mathbf{N}$ & $\mathrm{s}$ & $\begin{array}{l}\text { Pollination Strategies - Seed } \\
\text { Dispersal Strategies }\end{array}$ \\
\hline 1 & $\begin{array}{l}\text { Achillea maritima (L.) Ehrend. \& Y.P.Guo } \\
\text { subsp. maritima }\end{array}$ & Asteraceae & Ch suffr & Medit.-Atl. & & 1 & 1 & & & & 11 & 10 & 4 & 1 & 3 & 1 & 2 & $\mathrm{EP}-\mathrm{AC}$ \\
\hline 2 & Aeluropus lagopoides (L.) Trin. ex Thwaites & Poaceae & G rhiz & Medit.-Turan. & 1 & & & 1 & & 1 & 11 & 12 & 3 & 4 & 8 & 1 & 3 & $\mathrm{AP}-\mathrm{AC}$ \\
\hline 3 & Agave americana L. subsp. americana & Asparagaceae & P caesp & N-Americ. & 1 & & & 1 & & 1 & 9 & 10 & 2 & 2 & $\mathrm{x}$ & 2 & 0 & $E P-A C+A U C 1$ \\
\hline 4 & Ajuga iva (L.) Schreb. subsp. iva & Lamiaceae & Ch suffr & Steno-Medit. & 1 & 1 & & & & 1 & 8 & 8 & 4 & 3 & 7 & 2 & 0 & $E P-A C+Z C 3$ \\
\hline 5 & $\begin{array}{l}\text { Ajuga iva (L.) Schreb. subsp. pseudoiva } \\
\text { (DC.) Brig. }\end{array}$ & Lamiaceae & Ch suffr & Steno-Medit. & 1 & & & & & 1 & 8 & 8 & 4 & 3 & 7 & 2 & 0 & $\mathrm{EP}-\mathrm{AC}+\mathrm{ZC} 3$ \\
\hline 7 & Allium ampeloprasum $\mathrm{L}$. & Amaryllidaceae & G bulb & SE-Europ. & 1 & & & & & 1 & 7 & 7 & 5 & 3 & 6 & 5 & 0 & $\mathrm{EP}-\mathrm{AUC1}$ \\
\hline 6 & Allium nigrum $\mathrm{L}$. & Amaryllidaceae & G bulb & Steno-Medit. & & 1 & & & & & 10 & 9 & 4 & 3 & 6 & 4 & 0 & $\mathrm{EP}-\mathrm{AUC1}$ \\
\hline 9 & Allium subhirsutum L. subsp. subhirsutum & Amaryllidaceae & G bulb & W-Medit. & & 1 & & & & & 8 & 9 & 4 & 2 & 4 & 2 & 0 & $\mathrm{EP}-\mathrm{AUC1}$ \\
\hline 10 & Andropogon distachyos $\mathrm{L}$. & Poaceae & $\mathrm{H}$ caesp & Paleotrop. & 1 & & & & & 1 & 11 & 7 & 4 & 2 & 8 & 2 & 0 & $\mathrm{AP}-\mathrm{AC}$ \\
\hline 11 & Andryala integrifolia $\mathrm{L}$. & Asteraceae & T scap & Medit.-Atl. & 1 & & & & & 1 & 8 & 9 & 3 & 2 & 2 & 1 & 0 & $\mathrm{EP}-\mathrm{AC}$ \\
\hline 12 & $\begin{array}{l}\text { Anisantha fasciculata (C.Presl) Nevski } \\
\text { subsp. fasciculata }\end{array}$ & Poaceae & T scap & S-Medit. & 1 & & & & & 1 & 11 & 11 & 5 & 2 & 6 & 2 & 0 & $\mathrm{AP}-\mathrm{AUC2}$ \\
\hline 13 & $\begin{array}{l}\text { Anisantha madritensis (L.) Nevski subsp. } \\
\text { madritensis }\end{array}$ & Poaceae & T scap & Wide-Medit. & 1 & & & & & 1 & 8 & 7 & 5 & 3 & $\mathrm{x}$ & 1 & 0 & $\mathrm{AP}-\mathrm{AUC2}$ \\
\hline 14 & Anisantha rigida (Roth) Hyl. & Poaceae & T scap & Paleosubtrop. & 1 & & & & & 1 & 8 & 8 & 5 & 4 & 6 & 5 & 0 & $\mathrm{AP}-\mathrm{AUC2}$ \\
\hline 15 & Anthemis secundiramea Biv. & Asteraceae & T scap & S-Medit. & 1 & & & & & 1 & 11 & 11 & 5 & 1 & 3 & 1 & 0 & $E P-A C$ \\
\hline 16 & Anthoxanthum ovatum Lag. & Poaceae & T scap & W-Medit. & & & & & 1 & & 7 & 8 & 4 & 3 & 3 & 2 & 0 & $\mathrm{AP}-\mathrm{AUC2}$ \\
\hline 17 & Arenaria leptoclados (Rchb.) Guss. subsp. & Caryophyllaceae & T scap & Paleotemp. & 1 & 1 & 1 & & & 1 & 9 & 9 & 5 & 2 & 3 & 1 & 0 & $\mathrm{EP}-\mathrm{AC}+\mathrm{ZC} 3$ \\
\hline 20 & $\begin{array}{l}\text { Arthrocaulon meridionalis Es.Ramírez, } \\
\text { Rufo, Sánchez Mata, V.Fuente }\end{array}$ & Chenopodiaceae & Ch succ & Steno-Medit. & 1 & 1 & 1 & 1 & & 1 & 11 & 9 & 4 & 8 & 9 & 7 & 3 & $\mathrm{AP}-\mathrm{AC}$ \\
\hline 21 & Arundo donax $\mathrm{L}$. & Poaceae & G rhiz & Subcosmop. & & & & & & 1 & 8 & 9 & 5 & 5 & 5 & 6 & 0 & $\mathrm{AP}-\mathrm{AC}$ \\
\hline 22 & Asparagus acutifolius L. & Asparagaceae & G rhiz & Steno-Medit. & 1 & 1 & 1 & 1 & & 1 & 6 & 9 & 4 & 2 & 5 & 5 & 0 & $\mathrm{AP}+\mathrm{EP}-\mathrm{ZC} 2$ \\
\hline 23 & Asphodelus fistulosus L. & Asparagaceae & H scap & Paleosubtrop. & 1 & & & & & 1 & 11 & 8 & 5 & 2 & 4 & 2 & 0 & EP - AUC1 \\
\hline 24 & Asphodelus ramosus L. subsp. ramosus & Asphodelaceae & G rhiz & Steno-Medit. & 1 & 1 & & 1 & 1 & 1 & 10 & 9 & 4 & 2 & 3 & 5 & 0 & $E P-A U C 1$ \\
\hline 25 & Asteriscus aquaticus (L.) Less. & Asteraceae & T scap & Steno-Medit. & 1 & 1 & 1 & 1 & & 1 & 10 & 9 & 4 & 7 & 7 & 7 & 0 & $\mathrm{EP}-\mathrm{AC}+\mathrm{HC}$ \\
\hline 26 & Astragalus boeticus L. & Fabaceae & T scap & S-Medit. & 1 & 1 & & & & 1 & 11 & 11 & 5 & 1 & 3 & 1 & 0 & $\mathrm{EP}-\mathrm{BC}+\mathrm{AUC1}$ \\
\hline 27 & Atractylis cancellata $\mathrm{L}$. & Asteraceae & T scap & S-Medit. & 1 & & & & & 1 & 11 & 8 & 5 & 2 & 6 & 2 & 0 & $\mathrm{EP}-\mathrm{AC}$ \\
\hline 28 & $\begin{array}{l}\text { Avellinia festucoides (Link) Valdés \& } \\
\text { H.Scholz }\end{array}$ & Poaceae & T scap & Steno-Medit. & 1 & & & & & 1 & 10 & 9 & 4 & 2 & 5 & 1 & 0 & $\mathrm{AP}-\mathrm{AC}$ \\
\hline 29 & Avena barbata Pott ex Link & Poaceae & T scap & Medit.-Turan. & 1 & 1 & 1 & & & 1 & 8 & 8 & 5 & 3 & 7 & 2 & 0 & $\mathrm{AP}-\mathrm{AUC2}$ \\
\hline 30 & Avena sterilis L. subsp. sterilis & Poaceae & T scap & Wide-Medit. & 1 & & & & & 1 & 8 & 9 & 5 & 3 & 6 & 4 & 0 & $\mathrm{AP}-\mathrm{AUC2}$ \\
\hline
\end{tabular}


Table A1. Cont.

\begin{tabular}{|c|c|c|c|c|c|c|c|c|c|c|c|c|c|c|c|c|c|}
\hline $\mathbf{N}^{\circ}$ & Species & Family & Life Form & Chorotype & $\begin{array}{l}\text { This } \\
\text { Paper }\end{array}$ & $\begin{array}{c}\text { Albo } \\
(1919 ; \\
1957)^{*}\end{array}$ & $\begin{array}{l}\text { Pirola } \\
\text { (1959) }\end{array}$ & $\begin{array}{l}\text { Galletti } \\
\text { (1988) }\end{array}$ & $\begin{array}{l}\text { Camatta } \\
\text { et al. } \\
(1990)^{* *}\end{array}$ & $\begin{array}{c}\text { Cristaudo } \\
\text { and } \\
\text { Maugeri } \\
(2005)\end{array}$ & $\mathbf{L}$ & $\mathrm{TC}$ & C $\mathrm{L}$ & U R & $\mathrm{N}$ & $\mathrm{S}$ & $\begin{array}{l}\text { Pollination Strategies - Seed } \\
\text { Dispersal Strategies }\end{array}$ \\
\hline 31 & Barlia robertiana (Loisel.) Greuter & Orchidaceae & G bulb & Steno-Medit. & 1 & & & & & 1 & 7 & 94 & 43 & 36 & 2 & 0 & $\mathrm{EP}-\mathrm{AC}$ \\
\hline 32 & Bellardia trixago (L.) All. & Orchidaceae & T scap & Wide-Medit. & 1 & 1 & & & & 1 & 8 & 85 & 53 & $3 \quad 3$ & 3 & 0 & $\mathrm{EP}-\mathrm{AUC1}$ \\
\hline 33 & Bellis annua L. subsp. anпиа & Asteraceae & T scap & W-Medit. & 1 & & & & & 1 & 6 & 94 & $4 \quad 7$ & $\begin{array}{ll}7 \quad 2 \\
0\end{array}$ & 2 & 0 & $\mathrm{EP}-\mathrm{AC}$ \\
\hline 34 & Bellis sylvestris Cirillo & Asteraceae & H ros & Steno-Medit. & 1 & & & & & 1 & 5 & 84 & 43 & 33 & 3 & 0 & $\mathrm{EP}-\mathrm{AC}$ \\
\hline 35 & $\begin{array}{l}\text { Beta vulgaris L. subsp. maritima (L.) } \\
\text { Arcang. }\end{array}$ & Chenopodiaceae & H scap & Wide-Medit. & 1 & 1 & & 1 & & 1 & 10 & $7 \quad 5$ & 56 & 66 & 5 & 1 & $\mathrm{AP}-\mathrm{AC}$ \\
\hline 36 & Blackstonia perfoliata (L.) Huds. & Gentianaceae & T scap & Wide-Medit. & 1 & & & & & 1 & 8 & 75 & $5 \times$ & $\times 9$ & 4 & 0 & $\mathrm{EP}-\mathrm{AUC1}$ \\
\hline 37 & Borago officinalis $\mathrm{L}$. & Boraginaceae & T scap & Wide-Medit. & 1 & 1 & & & & 1 & 7 & 85 & 53 & 35 & 5 & 0 & $\mathrm{EP}-\mathrm{ZC} 3$ \\
\hline 39 & Brachypodium retusum (Pers.) P.Beauv. & Poaceae & H caesp & W-Medit. & 1 & & & & & 1 & 11 & 103 & 32 & 25 & 2 & 0 & $\mathrm{AP}-\mathrm{AUC2}$ \\
\hline 40 & Briza maxima $\mathrm{L}$. & Poaceae & T scap & Paleosubtrop. & 1 & 1 & & & 1 & 1 & 8 & 105 & 52 & 24 & 1 & 0 & $\mathrm{AP}-\mathrm{AC}$ \\
\hline 41 & Bromus hordeaceus L. subsp. hordeaceus & Poaceae & T scap & Subcosmop. & 1 & 1 & 1 & & & & 7 & 65 & $5 \times$ & $x \quad x$ & 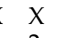 & 0 & $\mathrm{AP}-\mathrm{AUC2}$ \\
\hline 42 & Bromus scoparius L. & Poaceae & T scap & Steno-Medit. & 1 & & & & & & 11 & 94 & 42 & 26 & 2 & 0 & $\mathrm{AP}-\mathrm{AUC2}$ \\
\hline 43 & Cachrys libanotis L. & Apiaceae & H scap & W-Medit. & 1 & 1 & & & & 1 & 11 & 95 & 53 & $\begin{array}{ll}3 & 7\end{array}$ & 2 & 0 & $\mathrm{EP}-\mathrm{BC}$ \\
\hline 44 & Cachrys pungens Jan ex Guss. & Apiaceae & H scap & SW-Medit. & 1 & & & & & & 11 & 115 & 53 & 37 & 2 & 0 & $\mathrm{EP}-\mathrm{BC}$ \\
\hline 45 & Cachrys sicula L. & Apiaceae & H scap & W-Medit. & 1 & & & 1 & & & 11 & 104 & $4 \quad 2$ & 25 & 2 & 0 & $E P-B C$ \\
\hline 46 & Cakile maritima Scop. subsp. maritima & Apiaceae & T scap & Medit.-Atl. & 1 & 1 & & 1 & & 1 & 9 & 82 & 26 & $6 x$ & 8 & 3 & $\mathrm{EP}-\mathrm{AC}+\mathrm{HC}$ \\
\hline 47 & $\begin{array}{l}\text { Calamagrostis arenaria (L.) Roth subsp. } \\
\text { arundinacea (Husn.) Banfi, Galasso \& } \\
\text { Bartolucci }\end{array}$ & Poaceae & G rhiz & Wide-Medit. & 1 & 1 & 1 & 1 & 1 & 1 & 6 & $5 \quad 5$ & $5 \quad 5$ & $5 \quad 5$ & 5 & 0 & $\mathrm{AP}-\mathrm{AC}$ \\
\hline 48 & Calendula arvensis (Vaill.) L. & Asteraceae & T scap & Wide-Medit. & 1 & 1 & & & & 1 & 7 & 85 & 53 & 38 & 5 & 0 & $E P-A C+B C+Z C$ \\
\hline 49 & Campanula erinus $\mathrm{L}$. & Campanulaceae & T scap & Steno-Medit. & 1 & 1 & & & & 1 & 7 & $8 \quad 4$ & $4 \quad 2$ & $2 x$ & 1 & 0 & $\mathrm{EP}-\mathrm{AC}$ \\
\hline 52 & Carex divisa Huds. & Cyperaceae & G rhiz & Medit.-Atl. & 1 & & 1 & & & 1 & 8 & 82 & 23 & 35 & 3 & 0 & $\mathrm{AP}-\mathrm{AC}$ \\
\hline 53 & $\begin{array}{l}\text { Carex flacca Schreb. subsp. erythrostachys } \\
\text { (Hoppe) Holub }\end{array}$ & Cyperaceae & G rhiz & Europ. & 1 & & & & & 1 & 7 & $5 \quad 5$ & 56 & 68 & $x$ & 0 & $\mathrm{AP}-\mathrm{ZC}$ \\
\hline 54 & Carlina corymbosa $\mathrm{L}$. & Asteraceae & H scap & Steno-Medit. & 1 & & & & & & 6 & X 4 & $4 \quad 2$ & $2 x$ & 4 & 0 & $\mathrm{EP}-\mathrm{AC}$ \\
\hline 55 & Carlina gummifera (L.) Less. & Asteraceae & $\mathrm{H}$ ros & S-Medit. & 1 & & & & 1 & 1 & 11 & 115 & 51 & 17 & 1 & 0 & $\mathrm{EP}-\mathrm{AC}$ \\
\hline 56 & $\begin{array}{l}\text { Carlina hispanica Lam. subsp. globosa } \\
\text { (Arcang.) Meusel \& Kästner }\end{array}$ & Asteraceae & H scap & Steno-Medit. & 1 & & & & 1 & 1 & $x$ & $x \quad x$ & $x \quad x$ & $x \quad x$ & $x$ & $x$ & $\mathrm{EP}-\mathrm{AC}$ \\
\hline 57 & Carlina lanata $\mathrm{L}$. & Asteraceae & T scap & Steno-Medit. & 1 & & & & & 1 & 7 & 74 & 43 & 36 & 2 & 0 & $\mathrm{EP}-\mathrm{AC}$ \\
\hline 58 & Carlina sicula Ten. subsp. sicula & Asteraceae & H scap & Endem. Ital. & & & & & & 1 & 11 & 113 & 31 & 12 & 1 & 0 & $\mathrm{EP}-\mathrm{AC}$ \\
\hline 59 & Carthamus lanatus L. & Asteraceae & T scap & Wide-Medit. & 1 & & & & 1 & 1 & 10 & 85 & 53 & 35 & 6 & 0 & $\mathrm{EP}-\mathrm{AC}$ \\
\hline 60 & Catapodium balearicum (Willk.) H.Scholz & Poaceae & T scap & Medit.-Atl. & 1 & 1 & 1 & 1 & 1 & 1 & 11 & 103 & 31 & $1 \mathrm{X}$ & 1 & 2 & $\mathrm{AP}-\mathrm{AC}$ \\
\hline 61 & $\begin{array}{l}\text { Catapodium pauciflorum (Merino) Brullo, } \\
\text { Giusso, Miniss. \& Spamp. }\end{array}$ & Poaceae & T scap & Medit.-Atl. & 1 & & & & & & $x$ & $x \quad x$ & $x \quad x$ & $x \quad x$ & $x$ & $x$ & $\mathrm{AP}-\mathrm{AC}$ \\
\hline 62 & $\begin{array}{l}\text { Catapodium rigidum (L.) C.E.Hubb. subsp. } \\
\text { rividum }\end{array}$ & Poaceae & T scap & Wide-Medit. & 1 & 1 & 1 & & & 1 & 8 & 85 & 52 & 25 & 4 & 0 & $\mathrm{AP}-\mathrm{AC}$ \\
\hline 63 & Centaurea melitensis $\mathrm{L}$. & Asteraceae & T scap & Pantrop. & 1 & 1 & & & & 1 & 10 & 125 & $5 \quad 2$ & $2 x$ & 5 & 0 & $\mathrm{EP}-\mathrm{AC}+\mathrm{ZC} 3$ \\
\hline 64 & $\begin{array}{l}\text { Centaurea sphaerocephala L. subsp. } \\
\text { sphaerocephala }\end{array}$ & Asteraceae & H scap & W-Medit. & 1 & & 1 & 1 & & 1 & 11 & 104 & $4 \quad 1$ & $1 x$ & 1 & 0 & $\mathrm{EP}-\mathrm{AC}+\mathrm{ZC} 3$ \\
\hline 65 & Centaurium erythraea Rafn subsp. erythraea & Gentianaceae & H bienn & Eurasiat. & & 1 & & & & & 8 & 65 & 55 & 56 & $x$ & 0 & $\mathrm{EP}-\mathrm{AC}$ \\
\hline 66 & $\begin{array}{l}\text { Centaurium pulchellum (Sw.) Druce subsp. } \\
\text { pulchellum }\end{array}$ & Gentianaceae & T scap & Paleotemp. & 1 & & 1 & & & 1 & 9 & $6 \quad 7$ & $7 \quad 7$ & 79 & 3 & 0 & $\mathrm{EP}-\mathrm{AC}$ \\
\hline 67 & $\begin{array}{l}\text { Centaurium tenuiflorum (Hoffmanns. and } \\
\text { Link) Fritsch subsp. tenuiflorum }\end{array}$ & Gentianaceae & T scap & Paleotemp. & 1 & 1 & & & & 1 & 9 & 85 & 57 & $7 \quad 7$ & 2 & 0 & $\mathrm{EP}-\mathrm{AC}$ \\
\hline 68 & Cerastium glomeratum Thuill. & Gentianaceae & T scap & Subcosmop. & & 1 & & & & & 7 & $\times 5$ & 55 & 55 & 5 & 0 & $E P-A C+Z C 3$ \\
\hline 70 & Cerastium semidecandrum $\mathrm{L}$. & Caryophyllaceae & T scap & Cosmop. & 1 & & & & & 1 & 8 & 75 & 54 & $4 x$ & $6 x$ & 0 & $\mathrm{EP}-\mathrm{AC}+\mathrm{ZC} 3$ \\
\hline
\end{tabular}


Table A1. Cont.

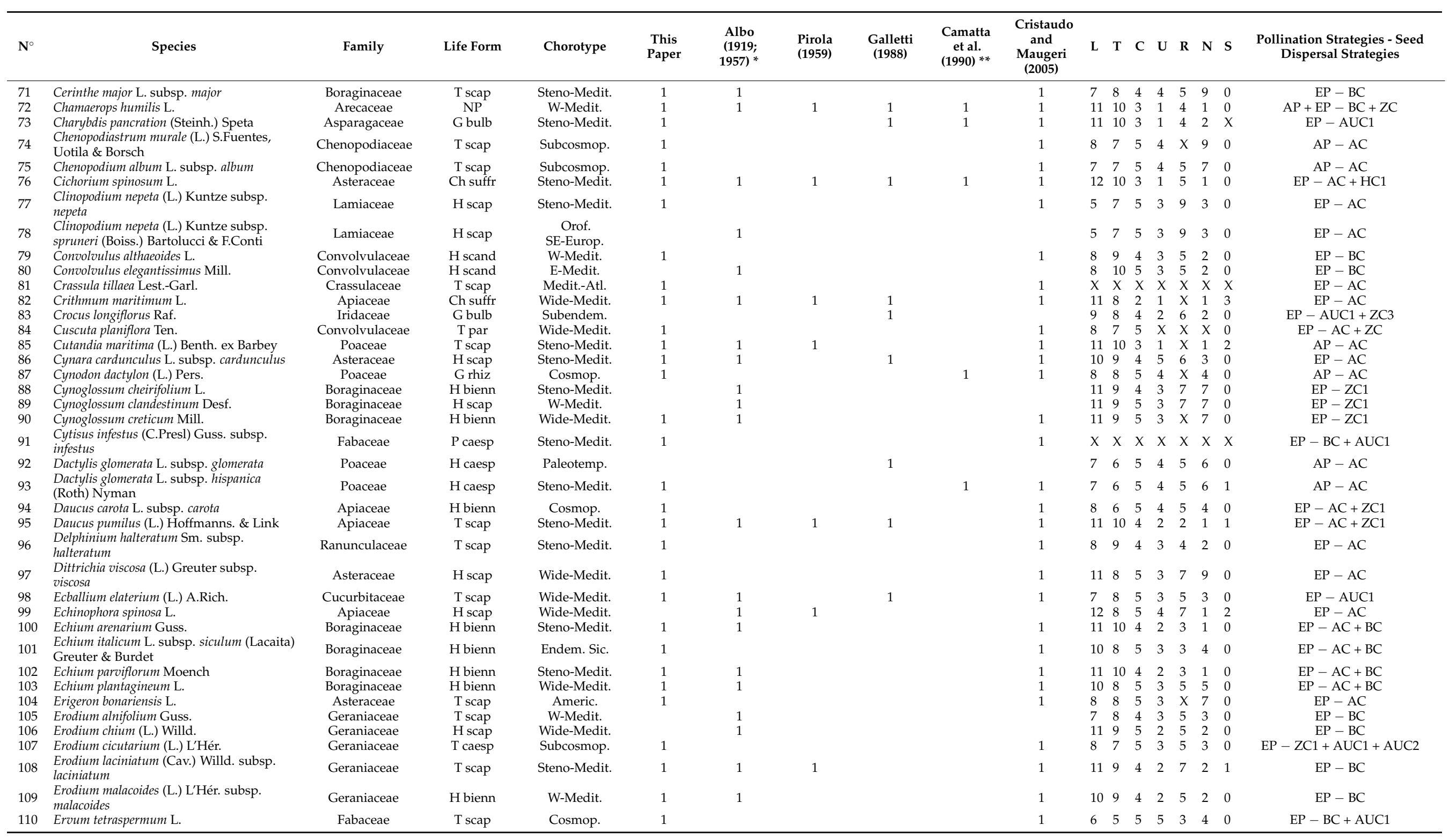


Table A1. Cont.

\begin{tabular}{|c|c|c|c|c|c|c|c|c|c|c|c|c|c|c|c|c|c|c|}
\hline $\mathbf{N}^{\circ}$ & Species & Family & Life Form & Chorotype & $\begin{array}{l}\text { This } \\
\text { Paper }\end{array}$ & $\begin{array}{c}\text { Albo } \\
\text { (1919; } \\
\text { 1957) * }\end{array}$ & $\begin{array}{l}\text { Pirola } \\
\text { (1959) }\end{array}$ & $\begin{array}{l}\text { Galletti } \\
\text { (1988) }\end{array}$ & $\begin{array}{l}\text { Camatta } \\
\text { et al. } \\
(1990) \text { ** }\end{array}$ & $\begin{array}{l}\text { Cristaudo } \\
\text { and } \\
\text { Maugeri } \\
(2005)\end{array}$ & $\mathrm{L}$ & $\mathrm{T}$ & C & $\mathrm{U}$ & $\mathbf{R}$ & $\mathbf{N}$ & $\mathrm{s}$ & $\begin{array}{l}\text { Pollination Strategies - Seed } \\
\text { Dispersal Strategies }\end{array}$ \\
\hline 111 & Eryngium campestre $\mathrm{L}$. & Apiaceae & H scap & Wide-Medit. & 1 & & & & & 1 & 9 & 7 & 5 & 3 & 8 & 3 & 0 & $\mathrm{EP}-\mathrm{AC}$ \\
\hline 112 & Eryngium maritimum L. & Apiaceae & G rhiz & Medit--Atl. & & & 1 & & & & 11 & 8 & 3 & 4 & 7 & 1 & 1 & $E P-A C+B C$ \\
\hline 113 & Euphorbia exigua L. subsp. exigua & Euphorbiaceae & T scap & Wide-Medit. & 1 & & & & & 1 & 10 & 9 & 5 & 2 & 6 & 1 & 0 & $\mathrm{EP}-\mathrm{AUC1}+\mathrm{ZC} 3$ \\
\hline 114 & Euphorbia helioscopia L. subsp. helioscopia & Euphorbiaceae & T scap & Cosmop. & 1 & & & & & 1 & 9 & 7 & 5 & 3 & 5 & 6 & 0 & $\mathrm{EP}-\mathrm{AUC1}+\mathrm{ZC} 3$ \\
\hline 115 & Euphorbia paralias L. & Euphorbiaceae & Ch frut & Medit.-Atl. & 1 & 1 & 1 & 1 & & 1 & 11 & 8 & 5 & 1 & $\mathrm{x}$ & 1 & 2 & $\mathrm{EP}-\mathrm{AUC1}+\mathrm{ZC} 3$ \\
\hline 116 & Euphorbia peplis L. & Euphorbiaceae & T rept & Wide-Medit. & 1 & & & 1 & & 1 & 11 & 7 & 2 & 1 & $x$ & 1 & 2 & $\mathrm{EP}-\mathrm{AUC1}+\mathrm{ZC} 3$ \\
\hline 117 & Euphorbia peplus L. & Euphorbiaceae & T scap & Cosmop. & 1 & 1 & & & & 1 & 6 & 7 & 4 & 4 & 5 & 7 & 0 & $\mathrm{EP}-\mathrm{AUC1}+\mathrm{ZC} 3$ \\
\hline 118 & Euphorbia terracina $\mathrm{L}$. & Euphorbiaceae & H scap & Steno-Medit. & 1 & 1 & & 1 & & 1 & 11 & 9 & 4 & 2 & 3 & 2 & 0 & $\mathrm{EP}-\mathrm{AUC1}+\mathrm{ZC} 3$ \\
\hline 122 & Filago germanica (L.) Huds. & Asteraceae & T scap & Paleotemp. & & 1 & 1 & & & & 8 & 7 & 5 & 3 & 4 & 2 & 0 & $\mathrm{EP}-\mathrm{AC}$ \\
\hline 123 & Filago pygmaea $\mathrm{L}$. & Asteraceae & T rept & Steno-Medit. & 1 & 1 & 1 & & 1 & 1 & 11 & 9 & 4 & 1 & 3 & 1 & 0 & $\mathrm{EP}-\mathrm{AC}$ \\
\hline 124 & Filago pyramidata $\mathrm{L}$. & Asteraceae & T scap & Wide-Medit. & 1 & & & & & 1 & 8 & 7 & 5 & 3 & 4 & 1 & 0 & $\mathrm{EP}-\mathrm{AC}$ \\
\hline 125 & $\begin{array}{l}\text { Foeniculum vulgare Mill. subsp. piperitum } \\
\text { (Ucria) Bég. }\end{array}$ & Apiaceae & H scap & S-Medit. & & & & & 1 & & 9 & 8 & 5 & 3 & 7 & 7 & 0 & $\mathrm{EP}-\mathrm{AC}+\mathrm{BC}$ \\
\hline 126 & Frankenia hirsuta $\mathrm{L}$ & Frankeniaceae & Ch suffr & $\begin{array}{l}\text { Steno-Medit.- } \\
\text { African }\end{array}$ & 1 & 1 & & 1 & & 1 & 11 & 10 & 4 & 1 & 7 & 1 & 3 & EP - AUC1 \\
\hline 127 & $\begin{array}{l}\text { Frankenia pulverulenta L. subsp. } \\
\text { pulverulenta }\end{array}$ & Frankeniaceae & T scap & $\begin{array}{l}\text { Steno-Medit.- } \\
\text { Asiatic }\end{array}$ & 1 & & & & & 1 & 11 & 9 & 4 & 1 & 7 & 1 & 2 & $\mathrm{EP}-\mathrm{AUC1}$ \\
\hline 128 & Fumaria flabellata Gasp. & Papaveraceae & T scap & Steno-Medit. & 1 & 1 & & & & 1 & 7 & 9 & 4 & 2 & 5 & 2 & 0 & $\mathrm{EP}-\mathrm{AC}+\mathrm{ZC} 3$ \\
\hline 129 & Galactites tomentosus Moench & Asteraceae & H bienn & Steno-Medit. & 1 & 1 & 1 & & 1 & 1 & 8 & 8 & 4 & 3 & $\mathrm{x}$ & 7 & 0 & $\mathrm{EP}-\mathrm{AC}$ \\
\hline 130 & Galium murale (L.) All. & Rubiaceae & T scap & Steno-Medit. & 1 & 1 & & & & 1 & 10 & 9 & 4 & 2 & $x$ & 1 & 0 & $A P+E P-A C$ \\
\hline 132 & $\begin{array}{l}\text { Gastridium ventricosum (Gouan) Schinz \& } \\
\text { Thell. }\end{array}$ & Poaceae & T scap & Medit.-Atl. & 1 & & & & & 1 & 8 & 9 & 4 & 2 & 4 & 2 & 0 & $\mathrm{AP}-\mathrm{AC}$ \\
\hline 133 & Geranium dissectum $\mathrm{L}$. & Geraniaceae & T scap & Cosmop. & 1 & & & & & 1 & 7 & 8 & 5 & 2 & 5 & 2 & 0 & $\mathrm{EP}-\mathrm{AUC1}$ \\
\hline 134 & Geranium molle L. & Geraniaceae & $\mathrm{H}$ bienn & Subcosmop. & 1 & 1 & & & & 1 & 7 & 6 & 5 & 3 & 5 & 4 & 0 & EP - AUC1 \\
\hline 135 & Gladiolus italicus Mill. & Iridaceae & G bulb & Wide-Medit. & 1 & 1 & & & & 1 & 9 & 9 & 5 & 3 & 5 & 3 & 0 & $\mathrm{EP}-\mathrm{AUC1}+\mathrm{ZC} 3$ \\
\hline 136 & Glaucium flavum Crantz & Papaveraceae & H scap & Wide-Medit. & 1 & 1 & & 1 & 1 & 1 & 11 & 9 & 5 & 1 & 4 & 1 & 1 & EP - AUC1 \\
\hline 137 & Halimione portulacoides (L.) Aellen & Chenopodiaceae & Ch frut & Circumbor. & 1 & & & 1 & & 1 & 11 & 9 & 4 & 2 & 6 & 7 & 3 & $\mathrm{AP}-\mathrm{AC}$ \\
\hline 138 & Hedypnois rhagadioloides (L.) F.W.Schmidt & Asteraceae & T scap & Steno-Medit. & 1 & & & & & 1 & 11 & 9 & 4 & 3 & 7 & 2 & 0 & $E P-A C+B C$ \\
\hline 139 & Heliotropium europaeum L. & Heliotropiaceae & T scap & Medit.-Turan. & 1 & 1 & & & & 1 & 10 & 8 & $\begin{array}{l}4 \\
5\end{array}$ & 3 & 7 & 2 & 1 & $E P-A C+B C$ \\
\hline 140 & Herniaria glabra L. subsp. glabra & Caryophyllaceae & T scap & Paleotemp. & & 1 & & & & & 9 & 5 & 5 & 4 & 2 & 2 & 0 & $\mathrm{EP}-\mathrm{AC}$ \\
\hline 141 & Herniaria hirsuta L. subsp. hirsuta & Caryophyllaceae & $\mathrm{H}$ caesp & Paleotemp. & & 1 & & & & & 9 & 6 & 5 & 4 & 2 & 2 & 0 & $\mathrm{EP}-\mathrm{AC}$ \\
\hline 142 & $\begin{array}{l}\text { Hirschfeldia incana (L.) Lagr.-Foss. subsp. } \\
\text { incana }\end{array}$ & Brassicaceae & H scap & Medit.-Atl. & 1 & 1 & & & & 1 & 9 & 9 & 5 & 3 & 3 & 2 & 0 & $\mathrm{EP}-\mathrm{AC}$ \\
\hline 143 & Hordeum bulbosum $\mathrm{L}$. & Poaceae & H caesp & Paleosubtrop. & & 1 & & & & & 8 & 10 & 5 & 4 & 5 & 4 & 0 & $\mathrm{AP}-\mathrm{AUC2}$ \\
\hline 144 & $\begin{array}{l}\text { Hordeum murinum L. subsp. leporinum } \\
\text { (Link) Arcang. }\end{array}$ & Poaceae & T scap & Wide-Medit. & 1 & & & & & 1 & 8 & 8 & 4 & 5 & 5 & 3 & 0 & $\mathrm{AP}-\mathrm{AUC2}$ \\
\hline 145 & $\begin{array}{l}\text { (Link) Arcang. } \\
\text { Hordeum murinum L. subsp. murinum }\end{array}$ & Poaceae & T scap & Circumbor. & & & 1 & & & & 8 & 8 & 4 & 5 & 5 & 3 & 0 & $\mathrm{AP}-\mathrm{AUC2}$ \\
\hline 146 & Hyoscyamus albus $\mathrm{L}$. & Solanaceae & $\mathrm{H}$ bienn & Wide-Medit. & 1 & 1 & & 1 & & 1 & 8 & 8 & 5 & 2 & $\mathrm{x}$ & 9 & 0 & $\mathrm{EP}-\mathrm{AC}$ \\
\hline 147 & Hyoseris scabra L. & Asteraceae & T ros & Steno-Medit. & 1 & 1 & 1 & & & 1 & 11 & 9 & 3 & 1 & 7 & 1 & 0 & $\mathrm{EP}-\mathrm{AC}$ \\
\hline 148 & Hyparrhenia hirta (L.) Stapf subsp. hirta & Poaceae & $\mathrm{H}$ caesp & Paleotrop. & 1 & & & & 1 & 1 & 11 & 12 & 5 & 2 & 7 & 3 & 0 & $\mathrm{AP}-\mathrm{AC}$ \\
\hline 149 & Hypericum perfoliatum $\mathrm{L}$. & Hypericaceae & H scap & Steno-Medit. & 1 & & & 1 & & 1 & 6 & 8 & 4 & 4 & 3 & 4 & 0 & $E P-A C+Z C$ \\
\hline 150 & Hypericum perforatum L. subsp. perforatum & Hypericaceae & H caesp & Cosmop. & 1 & 1 & & & 1 & & 7 & 8 & 6 & $x$ & $x$ & $x$ & 0 & $E P-A C+Z C$ \\
\hline
\end{tabular}


Table A1. Cont.

\begin{tabular}{|c|c|c|c|c|c|c|c|c|c|c|c|c|c|c|c|c|c|c|}
\hline $\mathbf{N}^{\circ}$ & Species & Family & Life Form & Chorotype & $\begin{array}{l}\text { This } \\
\text { Paper }\end{array}$ & $\begin{array}{c}\text { Albo } \\
(1919 ; \\
1957)^{*}\end{array}$ & $\begin{array}{l}\text { Pirola } \\
\text { (1959) }\end{array}$ & $\begin{array}{l}\text { Galletti } \\
\text { (1988) }\end{array}$ & $\begin{array}{l}\text { Camatta } \\
\text { et al. } \\
(1990)^{* *}\end{array}$ & $\begin{array}{c}\text { Cristaudo } \\
\text { and } \\
\text { Maugeri } \\
(2005)\end{array}$ & $\mathrm{L}$ & $\mathrm{T}$ & C & $\mathrm{U}$ & $\mathbf{R}$ & $\mathbf{N}$ & $\mathrm{s}$ & $\begin{array}{l}\text { Pollination Strategies - Seed } \\
\text { Dispersal Strategies }\end{array}$ \\
\hline 151 & Hypericum triquetrifolium Turra & Hypericaceae & H scap & E-Medit. & & & & & & 1 & 8 & 8 & 5 & 3 & 7 & 2 & 0 & $\mathrm{EP}-\mathrm{AC}+\mathrm{ZC}$ \\
\hline 152 & Hypochaeris achyrophorus L. & Asteraceae & T scap & Steno-Medit. & 1 & & 1 & & & 1 & 10 & 9 & 4 & 2 & $x$ & 2 & 0 & $\mathrm{EP}-\mathrm{AC}$ \\
\hline 153 & Juncus acutus L. subsp. acutus & Juncaceae & H caesp & Wide-Medit. & 1 & 1 & & & & 1 & 11 & 8 & 3 & 8 & 8 & 3 & 3 & $\mathrm{AP}-\mathrm{AC}$ \\
\hline 154 & Juno planifolia (Mill.) Asch. & Iridaceae & G bulb & S-Medit. & 1 & & & & & 1 & 8 & 8 & 3 & 3 & 4 & 2 & 0 & $\mathrm{EP}-\mathrm{AUC1}+\mathrm{ZC} 3$ \\
\hline 155 & Koeleria splendens C.Presi ${ }^{* *}$ & Poaceae & H caesp & $\begin{array}{l}\text { Orof. } \\
\text { S-Europ. }\end{array}$ & & 1 & & & & & 11 & 7 & 6 & 3 & 7 & 1 & 0 & $\mathrm{AP}-\mathrm{AC}$ \\
\hline 156 & $\begin{array}{l}\text { Lagurus ovatus L. subsp. nanus (Guss.) } \\
\text { Messeri }\end{array}$ & Poaceae & T scap & Steno-Medit. & 1 & & & & & 1 & 8 & 9 & 5 & 3 & $\mathrm{x}$ & 2 & 1 & $\mathrm{AP}-\mathrm{AC}$ \\
\hline 158 & Lathyrus clymenum L. & Fabaceae & T scap & Steno-Medit. & 1 & 1 & & & & & 7 & 8 & 4 & 4 & 3 & 3 & 0 & $\mathrm{EP}-\mathrm{BC}$ \\
\hline 159 & Lemna minor $\mathrm{L}$. & Araceae & Inat & Subcosmop. & & & & & & 1 & 7 & $\mathrm{x}$ & 5 & 12 & $\mathrm{x}$ & $\mathrm{x}$ & 0 & $\mathrm{HP}+\mathrm{EP}-\mathrm{HC} 1$ \\
\hline 160 & $\begin{array}{l}\text { Limbarda crithmoides (L.) Dumort. subsp. } \\
\text { longifolia (Arcang.) Greuter }\end{array}$ & Asteraceae & Ch suffr & Medit.-Atl. & 1 & & & & & 1 & 11 & 8 & 4 & 7 & 9 & 5 & 3 & $\mathrm{EP}-\mathrm{AC}$ \\
\hline 161 & Limonium hyblaeum Brullo* & Plumbaginaceae & H ros & Endem. Sic. & 1 & & & 1 & & 1 & $\mathrm{x}$ & $x$ & $\mathrm{x}$ & $x$ & $\mathrm{x}$ & $\mathrm{x}$ & $\mathrm{x}$ & $\mathrm{EP}-\mathrm{AC}$ \\
\hline 162 & Limonium narbonense Mill. & Plumbaginaceae & H ros & Wide-Medit. & 1 & & & & & 1 & 11 & 7 & 5 & 6 & 7 & 5 & 3 & $\mathrm{EP}-\mathrm{AC}$ \\
\hline 163 & Limonium sinuatum (L.) Mill. & Plumbaginaceae & H scap & S-Medit. & 1 & 1 & 1 & 1 & & 1 & 11 & 11 & 4 & 1 & 7 & 2 & 1 & $\mathrm{EP}-\mathrm{AC}$ \\
\hline 164 & Limonium syracusanum Brullo* & Plumbaginaceae & Ch sufrr & Endem. Sic. & 1 & & & & & & $\mathrm{x}$ & $\mathrm{x}$ & $\mathrm{x}$ & $\mathrm{x}$ & $\mathrm{x}$ & $\mathrm{x}$ & $\mathrm{x}$ & $\mathrm{EP}-\mathrm{AC}$ \\
\hline 165 & Limonium virgatum (Willd.) Fourr. & Plumbaginaceae & H ros & Wide-Medit. & 1 & 1 & 1 & 1 & & 1 & 9 & 9 & 3 & 1 & 9 & 1 & 3 & $\mathrm{EP}-\mathrm{AC}$ \\
\hline 166 & Linaria reflexa (L.) Desf. subsp. reflexa & Plantaginaceae & Trept & SW-Medit. & 1 & & & & & 1 & 7 & 8 & 5 & 3 & 5 & 3 & 0 & $\mathrm{EP}-\mathrm{AC}$ \\
\hline 167 & Linum strictum L. & Linaceae & T scap & Steno-Medit. & 1 & & & & & 1 & 11 & 9 & 4 & 2 & 5 & 2 & 0 & $\mathrm{EP}-\mathrm{AC}+\mathrm{ZC}$ \\
\hline 168 & Linum trigynum $\mathrm{L}$. & Linaceae & T scap & Wide-Medit. & 1 & & & & & 1 & 10 & 9 & 5 & 2 & 3 & 2 & 0 & $\mathrm{EP}-\mathrm{AC}+\mathrm{ZC}$ \\
\hline 169 & Lithospermum officinale $\mathrm{L}$. & Boraginaceae & H scap & Eurosiber. & & 1 & & & & & 6 & $x$ & 5 & $x$ & 8 & 6 & 0 & $E P-B C+Z C$ \\
\hline 172 & Loncomelos narbonensis (L.) Raf. & Asparagaceae & G bulb & Wide-Medit. & 1 & 1 & & & & 1 & 8 & 7 & 5 & 4 & 6 & 4 & 0 & $\mathrm{EP}-\mathrm{AUC1}+\mathrm{ZC} 3$ \\
\hline 173 & Lotus creticus L. & Fabaceae & Ch suffr & Steno-Medit. & 1 & 1 & 1 & 1 & 1 & 1 & 11 & 10 & 3 & 1 & $\mathrm{x}$ & 1 & 2 & $\mathrm{EP}-\mathrm{BC}$ \\
\hline 174 & Lotus cytisoides $\mathrm{L}$. & Fabaceae & Ch suffr & Steno-Medit. & 1 & & & & & 1 & 11 & 10 & 3 & 1 & $\mathrm{x}$ & 1 & 2 & $\mathrm{EP}-\mathrm{BC}$ \\
\hline 175 & Lotus edulis $\mathrm{L}$. & Fabaceae & T scap & Steno-Medit. & 1 & 1 & & & 1 & 1 & 9 & 8 & 4 & 2 & 5 & 3 & 0 & $\mathrm{EP}-\mathrm{BC}$ \\
\hline 176 & Lotus ornithopodioides L. & Fabaceae & T scap & Steno-Medit. & 1 & & & & & 1 & 10 & 9 & 4 & 2 & 1 & 1 & 0 & $\mathrm{EP}-\mathrm{BC}$ \\
\hline 177 & Lotus tetragonolobus $\mathrm{L}$. & Fabaceae & T scap & Steno-Medit. & 1 & & & & & 1 & 8 & 6 & 4 & 6 & 9 & 6 & 0 & $\mathrm{EP}-\mathrm{BC}$ \\
\hline 178 & $\begin{array}{l}\text { Lysimachia arvensis (L.) U. Manns \& } \\
\text { Anderb. subsp. arvensis }\end{array}$ & Primulaceae & T rept & Wide-Medit. & 1 & & & & & 1 & 6 & 6 & 5 & 5 & $x$ & 6 & 0 & $\mathrm{EP}-\mathrm{AUC1}$ \\
\hline 179 & $\begin{array}{l}\text { Lysimachia foemina (Mill.) U. Manns \& } \\
\text { Anderb. }\end{array}$ & Primulaceae & Trept & Subcosmop. & & 1 & & & & & 8 & 7 & 5 & 4 & 9 & 5 & 0 & EP - AUC1 \\
\hline 180 & Lythrum hyssopifolia L. & Lythraceae & T scap & Subcosmop. & 1 & & & & & 1 & 8 & 7 & 5 & 7 & 3 & 4 & 0 & $\mathrm{EP}-\mathrm{AC}+\mathrm{HC}+\mathrm{ZC}$ \\
\hline 181 & Malva cretica Cav. subsp. cretica & Malvaceae & T scap & Steno-Medit. & 1 & & & & & 1 & 7 & 7 & 4 & 4 & 7 & 8 & 0 & $E P-A C+B C$ \\
\hline 182 & Malva sylvestris $\mathrm{L}$. & Malvaceae & H scap & Subcosmop. & 1 & & & & & 1 & 8 & 6 & 4 & 4 & $\mathrm{x}$ & 8 & 0 & $E P-A C+B C$ \\
\hline 183 & Mandragora autumnalis Bertol. & Solanaceae & $\mathrm{H}$ ros & Steno-Medit. & 1 & 1 & & 1 & & 1 & 7 & 9 & 4 & 2 & 7 & 3 & 0 & $E P-Z C 2$ \\
\hline 184 & Marrubium vulgare $\mathrm{L}$. & Lamiaceae & H scap & Cosmop. & 1 & 1 & & 1 & & 1 & 9 & 8 & 5 & 3 & 8 & 8 & 0 & $\mathrm{EP}-\mathrm{AC}+\mathrm{ZC}$ \\
\hline 185 & Matthiola tricuspidata (L.) R.Br. & Brassicaceae & T scap & Steno-Medit. & 1 & & & 1 & & 1 & 11 & 10 & 4 & 1 & 3 & 1 & 1 & $\mathrm{EP}-\mathrm{AC}$ \\
\hline 186 & Medicago littoralis Rohde ex Loisel. & Fabaceae & T scap & Wide-Medit. & 1 & & 1 & & 1 & 1 & 11 & 9 & 5 & 2 & $\mathrm{x}$ & 2 & 0 & $\mathrm{EP}-\mathrm{ZC} 1$ \\
\hline 187 & Medicago minima (L.) L. & Fabaceae & T scap & $\begin{array}{l}\text { Wide-Medit.- } \\
\text { Asiatic }\end{array}$ & 1 & & & & 1 & 1 & 10 & 7 & 5 & 3 & 8 & 1 & 0 & $\mathrm{EP}-\mathrm{ZC} 1$ \\
\hline 188 & Medicago orbicularis (L.) Bartal. & Fabaceae & T scap & Wide-Medit. & 1 & & & & 1 & 1 & 7 & 8 & 5 & 3 & & 4 & 0 & $\mathrm{EP}-\mathrm{BC}$ \\
\hline 189 & Medicago polymorpha L. & Fabaceae & T scap & Subcosmop. & 1 & & & & & 1 & 9 & 9 & 5 & 2 & $\mathrm{x}$ & 2 & 0 & $\mathrm{EP}-\mathrm{ZC} 1$ \\
\hline 190 & Medicago truncatula Gaertn. & Fabaceae & T scap & Steno-Medit. & 1 & & & & & 1 & 11 & 8 & 4 & 1 & $\mathrm{x}$ & 1 & 1 & $\mathrm{EP}-\mathrm{ZC} 1$ \\
\hline
\end{tabular}


Table A1. Cont.

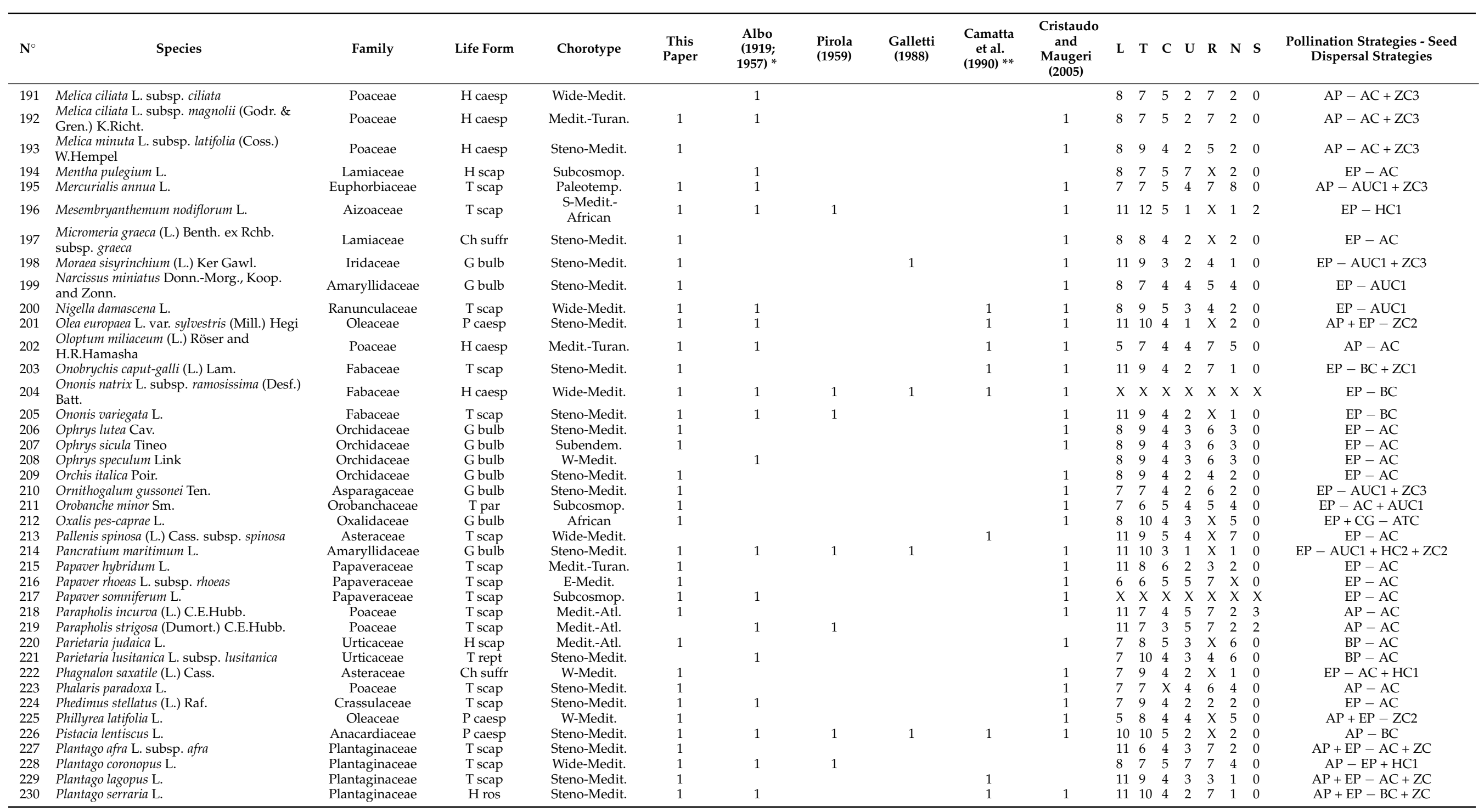


Table A1. Cont.

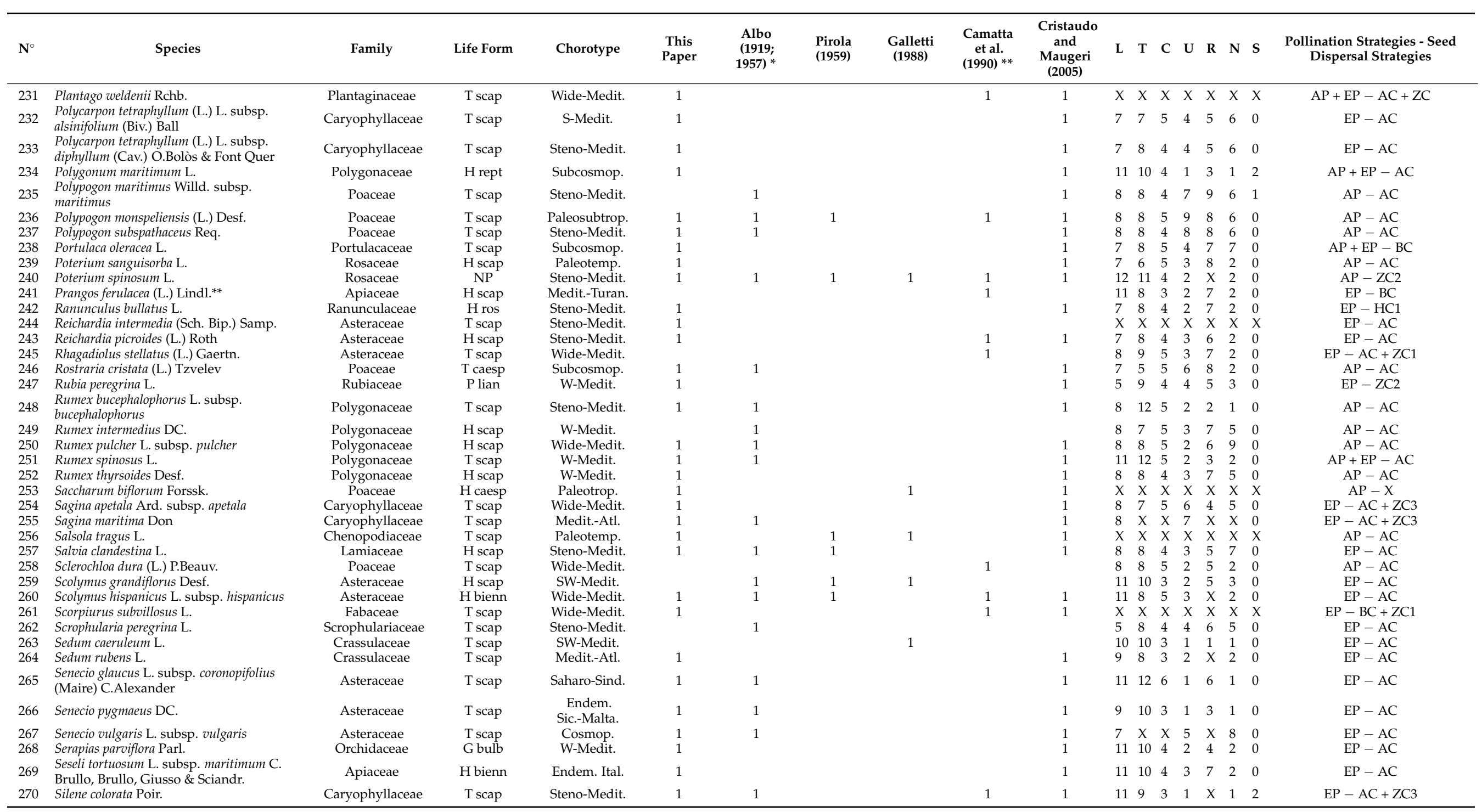


Table A1. Cont.

\begin{tabular}{|c|c|c|c|c|c|c|c|c|c|c|c|c|c|c|c|c|c|c|}
\hline $\mathbf{N}^{\circ}$ & Species & Family & Life Form & Chorotype & $\begin{array}{l}\text { This } \\
\text { Paper }\end{array}$ & $\begin{array}{c}\text { Albo } \\
\text { (1919; } \\
\text { 1957) * }\end{array}$ & $\begin{array}{l}\text { Pirola } \\
\text { (1959) }\end{array}$ & $\begin{array}{l}\text { Galletti } \\
\text { (1988) }\end{array}$ & $\begin{array}{l}\text { Camatta } \\
\text { et al. } \\
(1990)^{* *}\end{array}$ & $\begin{array}{l}\text { Cristaudo } \\
\text { and } \\
\text { Maugeri } \\
(2005)\end{array}$ & $\mathrm{L}$ & $\mathrm{T}$ & C & $\mathrm{U}$ & $\mathbf{R}$ & $\mathbf{N}$ & $\mathrm{S}$ & $\begin{array}{c}\text { Pollination Strategies - Seed } \\
\text { Dispersal Strategies }\end{array}$ \\
\hline 271 & Silene niceensis All. & Caryophyllaceae & T scap & Steno-Medit. & 1 & 1 & 1 & & & 1 & 11 & 10 & 4 & 2 & 3 & 1 & 1 & $\mathrm{EP}-\mathrm{AC}+\mathrm{ZC} 3$ \\
\hline 272 & Silene sedoides Poir. subsp. sedoides & Caryophyllaceae & T scap & Steno-Medit. & 1 & 1 & & & & 1 & 11 & 10 & 3 & 2 & 2 & 1 & 1 & $E P-A C+Z C 3$ \\
\hline 273 & $\begin{array}{l}\text { Silene vulgaris (Moench) Garcke subsp. } \\
\text { tenoreana (Colla) Soldano \& F Conti }\end{array}$ & Caryophyllaceae & H scap & E-Medit. & 1 & 1 & & & & 1 & 8 & $x$ & $x$ & 4 & 7 & 2 & 0 & $\mathrm{EP}-\mathrm{AC}+\mathrm{ZC} 3$ \\
\hline 274 & Sixalix atropurpurea (L.) Greuter \& Burdet & Dipsacaceae & H bienn & Steno-Medit. & 1 & & & & 1 & 1 & 6 & 8 & 4 & 3 & $x$ & 2 & 0 & $E P-A C+Z C$ \\
\hline 275 & Smilax aspera L. & Smilacaceae & G rhiz & Paleosubtrop. & 1 & & & & 1 & 1 & 6 & 10 & 4 & 2 & 5 & 3 & 0 & $\mathrm{AP}+\mathrm{EP}-\mathrm{ZC} 2$ \\
\hline 276 & Solanum dulcamara $\mathrm{L}$. & Solanaceae & NP & Paleotemp. & & 1 & & & & & 7 & 5 & $x$ & 8 & $x$ & 8 & 0 & $\mathrm{EP}-\mathrm{ZC} 2$ \\
\hline 277 & $\begin{array}{l}\text { Solanum linnaeanum Hepper \& } \\
\text { P.-M.L.Jaeger }\end{array}$ & Solanaceae & $\mathrm{NP}$ & African & & 1 & & & & & 9 & 11 & 5 & 2 & $x$ & 1 & 0 & $\mathrm{EP}-\mathrm{ZC} 2$ \\
\hline 278 & Solanum nigrum $\mathrm{L}$. & Solanaceae & T scap & Cosmop. & 1 & 1 & & & & 1 & 7 & 6 & 5 & 3 & 5 & 7 & 0 & $E P-Z C 2$ \\
\hline 279 & Sonchus asper (L.) Hill subsp. asper & Asteraceae & T scap & Cosmop. & 1 & & & & & 1 & 7 & 5 & $\mathrm{x}$ & 4 & 7 & 7 & 0 & $\mathrm{EP}-\mathrm{AC}$ \\
\hline 280 & $\begin{array}{l}\text { Sonchus bulbosus (L.) N.Kilian \& Greuter } \\
\text { subsp. bulbosus }\end{array}$ & Asteraceae & G bulb & Steno-Medit. & 1 & 1 & & & & 1 & 7 & 8 & 4 & 3 & 5 & 3 & 0 & $\mathrm{EP}-\mathrm{AC}$ \\
\hline 281 & $\begin{array}{l}\text { Subsp. ouvoosus } \\
\text { Sonchus oleraceus L. }\end{array}$ & Asteraceae & T scap & Cosmop. & 1 & & & & & 1 & 7 & 5 & $x$ & 4 & 8 & 8 & 0 & $\mathrm{EP}-\mathrm{AC}$ \\
\hline 282 & Sonchus tenerrimus $\mathrm{L}$. & Asteraceae & T scap & Steno-Medit. & 1 & & & & & 1 & 7 & 8 & 4 & 2 & 5 & 4 & 0 & $\mathrm{EP}-\mathrm{AC}$ \\
\hline 285 & Spergularia bocconei (Scheele) Graebn. & Caryophyllaceae & T scap & Subcosmop. & 1 & & & & & & 7 & 7 & $x$ & 6 & 3 & 4 & 0 & $E P-A C+Z C 3$ \\
\hline 283 & $\begin{array}{l}\text { Spergularia heldreichii E.Simon \& } \\
\text { P.Monnier }\end{array}$ & Caryophyllaceae & T scap & Steno-Medit. & 1 & & & & & 1 & 11 & 9 & 3 & 2 & 2 & 1 & 2 & $\mathrm{EP}-\mathrm{AC}+\mathrm{ZC} 3$ \\
\hline 284 & Spergularia marina (L.) Besser & Caryophyllaceae & T scap & Subcosmop. & 1 & & 1 & & & 1 & 7 & 7 & 5 & 6 & 8 & $\mathrm{x}$ & 2 & $\mathrm{EP}-\mathrm{AC}+\mathrm{ZC} 3$ \\
\hline 286 & Sporobolus virginicus (L.) Kunth & Poaceae & G rhiz & Subtrop. & 1 & 1 & 1 & 1 & & & 11 & 11 & 4 & 1 & $\mathrm{x}$ & 1 & 3 & $\mathrm{AP}-\mathrm{AC}$ \\
\hline 287 & Stachys major (L.) Bartolucci \& Peruzzi & Lamiaceae & Ch frut & Steno-Medit. & 1 & 1 & & 1 & & 1 & 11 & 10 & 4 & 2 & $x$ & 1 & 0 & $\mathrm{EP}-\mathrm{AC}$ \\
\hline 288 & Stachys romana (L.) E.H.L.Krause & Lamiaceae & T scap & Steno-Medit. & 1 & 1 & 1 & & & 1 & 11 & 9 & 4 & 2 & 6 & 1 & 0 & $\mathrm{EP}-\mathrm{AC}$ \\
\hline 290 & Suaeda maritima (L.) Dumort. & Chenopodiaceae & T scap & Cosmop. & & & & 1 & & & 9 & 6 & 2 & 8 & 7 & 7 & 3 & $\mathrm{AP}-\mathrm{AC}$ \\
\hline 291 & Suaeda vera J.F.Gmel. & Chenopodiaceae & $\mathrm{NP}$ & Cosmop. & 1 & 1 & & & & 1 & 11 & 10 & 5 & 8 & 9 & 7 & 3 & $\mathrm{AP}-\mathrm{AC}$ \\
\hline 292 & $\begin{array}{l}\text { Sulla spinosissima (L.) B.H.Choi \& } \\
\text { H.Ohashi }\end{array}$ & Fabaceae & T scap & W-Medit. & 1 & & & & & 1 & 11 & 9 & 4 & 2 & 3 & 2 & 0 & $\mathrm{EP}-\mathrm{ZC} 1$ \\
\hline 293 & $\begin{array}{l}\text { Symphyotrichum squamatum (Spreng.) } \\
\text { G.L.Nesom }\end{array}$ & Asteraceae & T scap & Neotrop. & 1 & & & & & 1 & 8 & 8 & 5 & 4 & 7 & 7 & 0 & $\mathrm{EP}-\mathrm{AC}$ \\
\hline 294 & Teucrium fruticans L. subsp. fruticans & Lamiaceae & NP & W-Medit. & 1 & & & 1 & 1 & 1 & 11 & 8 & 4 & 2 & 7 & 2 & 0 & $\mathrm{EP}-\mathrm{AC}$ \\
\hline 295 & Thapsia garganica L. subsp. garganica & Apiaceae & H scap & S-Medit. & 1 & 1 & 1 & & 1 & 1 & 11 & 8 & 5 & 3 & 5 & 3 & 0 & $E P-A C+Z C 1$ \\
\hline 296 & Theligonum cynocrambe L. & Rubiaceae & T scap & Steno-Medit. & 1 & & & & & 1 & 10 & 9 & 4 & 2 & 3 & 4 & 0 & $\mathrm{EP}-\mathrm{AC}$ \\
\hline 297 & Thinopyrum junceum (L.) Á.Löve & Poaceae & G rhiz & Wide-Medit. & & & & 1 & & & 12 & 6 & 5 & 7 & 7 & 7 & 2 & $\mathrm{AP}-\mathrm{AC}$ \\
\hline 298 & Thymelaea hirsuta (L.) Endl. & Thymelaeaceae & Ch suffr & $\begin{array}{l}\text { S-Medit.-W- } \\
\text { Asiatic }\end{array}$ & 1 & 1 & & 1 & & 1 & 11 & 8 & 5 & 2 & $x$ & 3 & 1 & $\mathrm{EP}-\mathrm{AUC1}$ \\
\hline 299 & Thymelaea passerina (L.) Coss. \& Germ. & Thymelaeaceae & T scap & $\begin{array}{l}\text { Wide-Medit.- } \\
\text { Asiatic }\end{array}$ & & 1 & & & & & 8 & 7 & 5 & 3 & 7 & 2 & 0 & $\mathrm{EP}-\mathrm{AUC1}$ \\
\hline 300 & Tordylium apulum $\mathrm{L}$. & Apiaceae & T scap & Steno-Medit. & 1 & & & & & 1 & 11 & 9 & 4 & 2 & $x$ & 2 & 0 & $\mathrm{EP}-\mathrm{AC}$ \\
\hline 301 & $\begin{array}{l}\text { Trifolium angustifolium L. subsp. } \\
\text { angustifolium }\end{array}$ & Fabaceae & T scap & Wide-Medit. & & & & & 1 & & 10 & 9 & 5 & 2 & 3 & 2 & 0 & $\mathrm{EP}-\mathrm{AC}$ \\
\hline 302 & Trifolium campestre Schreb. & Fabaceae & T scap & Paleotemp. & 1 & & & & & 1 & 8 & 5 & 5 & 4 & $x$ & 3 & 0 & $\mathrm{EP}-\mathrm{AC}$ \\
\hline 303 & Trifolium nigrescens Viv. subsp. nigrescens & Fabaceae & T scap & Wide-Medit. & 1 & & & & & 1 & 8 & 6 & 5 & 5 & 5 & 6 & 0 & $\mathrm{EP}-\mathrm{AC}$ \\
\hline 304 & Trifolium scabrum L. & Fabaceae & T rept & Wide-Medit. & 1 & & & & & 1 & 10 & 8 & 5 & 2 & 9 & 1 & 0 & $\mathrm{EP}-\mathrm{AC}$ \\
\hline 305 & Trifolium squarrosum $\mathrm{L}$. & Fabaceae & T scap & Wide-Medit. & & & & & 1 & & 10 & 9 & 5 & 2 & 3 & 2 & 0 & $\mathrm{EP}-\mathrm{AC}$ \\
\hline 306 & Trifolium stellatum $\mathrm{L}$. & Fabaceae & T scap & Wide-Medit. & 1 & & & & & 1 & 10 & 9 & 5 & 2 & $\mathrm{x}$ & 2 & 0 & $\mathrm{EP}-\mathrm{AC}$ \\
\hline 307 & Trifolium tomentosum $\mathrm{L}$. & Fabaceae & T rept & Paleotemp. & 1 & & & & & 1 & 9 & 9 & 5 & 4 & 7 & 2 & 0 & $\mathrm{EP}-\mathrm{AC}$ \\
\hline 308 & Triglochin laxiflora Guss. & Juncaginaceae & G bulb & W-Medit. & 1 & & & & & 1 & 8 & 8 & 4 & 8 & 7 & 7 & 0 & $\mathrm{AP}-\mathrm{AUC1}$ \\
\hline 309 & Trigonella foenum-graecum $\mathrm{L}$. & Fabaceae & T scap & W-Asiatic & & & & & 1 & & 9 & 9 & 5 & 2 & $x$ & 4 & 0 & $\mathrm{EP}-\mathrm{AC}$ \\
\hline
\end{tabular}


Table A1. Cont.

\begin{tabular}{|c|c|c|c|c|c|c|c|c|c|c|c|c|c|c|c|c|c|c|}
\hline $\mathbf{N}^{\circ}$ & Species & Family & Life Form & Chorotype & $\begin{array}{l}\text { This } \\
\text { Paper }\end{array}$ & $\begin{array}{c}\text { Albo } \\
\text { (1919; } \\
\text { 1957) * }\end{array}$ & $\begin{array}{l}\text { Pirola } \\
\text { (1959) }\end{array}$ & $\begin{array}{l}\text { Galletti } \\
\text { (1988) }\end{array}$ & $\begin{array}{l}\text { Camatta } \\
\text { et al. } \\
(1990) * *\end{array}$ & $\begin{array}{l}\text { Cristaudo } \\
\text { and } \\
\text { Maugeri } \\
(2005)\end{array}$ & $\mathbf{L}$ & $\mathrm{T}$ & C & $\mathrm{U}$ & $\mathbf{R}$ & $\mathbf{N} s$ & $\mathrm{~s}$ & $\begin{array}{l}\text { Pollination Strategies - Seed } \\
\text { Dispersal Strategies }\end{array}$ \\
\hline 311 & Tuberaria guttata (L.) Fourr. & Cistaceae & T scap & Wide-Medit. & & & & & 1 & & 11 & 9 & 5 & 2 & 1 & 10 & 0 & $\mathrm{EP}-\mathrm{BC}$ \\
\hline 312 & Typha domingensis (Pers.) Steud. & Typhaceae & G rhiz & Cosmop. & 1 & & & & & 1 & $\mathrm{x}$ & $x$ & $\mathrm{x}$ & $x$ & $\mathrm{x}$ & 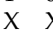 & $x$ & $\mathrm{AP}-\mathrm{AC}$ \\
\hline 313 & Umbilicus horizontalis (Guss.) DC. & Crassulaceae & G bulb & Medit-Atl. & & 1 & & & & & 5 & 8 & 4 & 3 & $x$ & $3 \quad 0$ & 0 & $\mathrm{EP}-\mathrm{AC}$ \\
\hline 314 & Urospermum dalechampii (L.) F.W.Schmidt & Asteraceae & H scap & Medit.-Atl. & 1 & 1 & & & & 1 & 8 & 8 & 5 & 3 & $\mathrm{x}$ & 30 & 0 & $\mathrm{EP}-\mathrm{AC}$ \\
\hline 315 & $\begin{array}{l}\text { Urospermum picroides (L.) Scop. ex } \\
\text { F.W.Schmidt }\end{array}$ & Asteraceae & T scap & Wide-Medit. & 1 & 1 & & & & 1 & 11 & 9 & 5 & 2 & $x$ & 20 & 0 & $\mathrm{EP}-\mathrm{AC}$ \\
\hline 316 & Urtica membranacea Poir. & Urticaceae & T scap & S-Medit. & 1 & 1 & & & & 1 & 7 & 8 & 5 & 3 & 6 & 30 & 0 & $\mathrm{BP}-\mathrm{AC}$ \\
\hline 317 & Urtica urens L. & Urticaceae & T scap & Subcosmop. & & 1 & & & & & 7 & 6 & $\mathrm{x}$ & 5 & 7 & $8 \begin{array}{cc}8 & 9 \\
8 & 0\end{array}$ & 0 & $\mathrm{BP}-\mathrm{AC}$ \\
\hline 318 & Valantia muralis L. & Rubiaceae & T scap & Steno-Medit. & 1 & 1 & 1 & 1 & & 1 & 10 & 9 & 4 & 2 & 3 & 10 & 0 & $\mathrm{EP}-\mathrm{AC}$ \\
\hline 320 & Verbascum sinuatum L. & Scrophulariaceae & H bienn & Wide-Medit. & 1 & 1 & 1 & 1 & & 1 & 9 & 8 & 5 & 3 & 7 & 7 & 0 & $E P-A C+Z C$ \\
\hline 321 & Verbascum thapsus L. subsp. thapsus & Scrophulariaceae & H bienn & Europ.- & & 1 & & & & & 8 & $x$ & 4 & 4 & 7 & 7 & 0 & $\mathrm{EP}-\mathrm{AC}+\mathrm{ZC}$ \\
\hline 322 & Vicia benghalensis $\mathrm{L}$. & Fabaceae & T scap & Steno-Medit. & 1 & & & & & 1 & 11 & 9 & 4 & 2 & 5 & 2 & 0 & $\mathrm{EP}-\mathrm{BC}+\mathrm{AUC1}$ \\
\hline 323 & Vicia bithynica (L.) L. & Fabaceae & T scap & Wide-Medit. & 1 & & & & & 1 & 7 & & 5 & 3 & 5 & 5 & 0 & $\mathrm{EP}-\mathrm{BC}+\mathrm{AUC1}$ \\
\hline 324 & Vicia leucantha Biv. & Fabaceae & T scap & SW-Medit. & & & & & & 1 & 11 & 11 & 5 & 2 & 7 & 2 & 0 & $\mathrm{EP}-\mathrm{BC}+\mathrm{AUC1}$ \\
\hline 325 & Vicia macrocarpa (Moris) Bertol. & Fabaceae & T scap & Medit.-Turan. & & 1 & & & & & 5 & 5 & 6 & $x$ & $x$ & $x$ & 0 & $\mathrm{EP}-\mathrm{BC}+\mathrm{AUC1}$ \\
\hline 326 & Vicia sativa L. & Fabaceae & T scap & Subcosmop. & 1 & & & & & 1 & 5 & 5 & 6 & $x$ & $\mathrm{x}$ & $x$ & 0 & $\mathrm{EP}-\mathrm{BC}+\mathrm{AUC1}$ \\
\hline 327 & Vicia villosa Roth & Fabaceae & T scap & Steno-Medit. & 1 & & & & & & 7 & 6 & 5 & 4 & $\hat{4}$ & $\hat{5}$ & 0 & $\mathrm{EP}-\mathrm{BC}+\mathrm{AUC1}$ \\
\hline \multirow[t]{2}{*}{328} & Xanthium italicum Moretti & Asteraceae & T scap & S-Europ. & 1 & & & & & 1 & 8 & 7 & 5 & 5 & $\mathrm{X}$ & 1 & 0 & $E P-Z C 1$ \\
\hline & & & & TOTAL & 269 & 147 & 54 & 57 & 55 & 257 & & & & & & & & \\
\hline
\end{tabular}

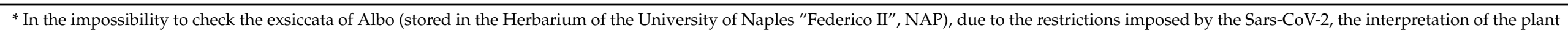

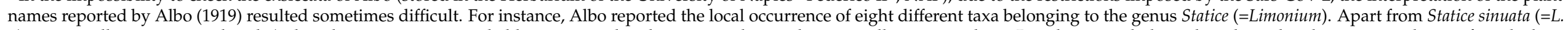

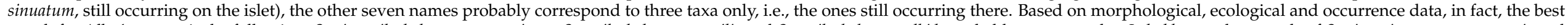

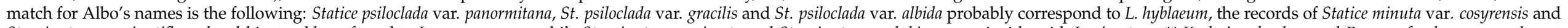

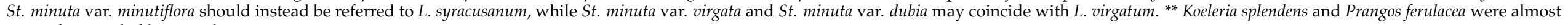
certainly recorded by mistake. 
Appendix B. Syntaxonomical Scheme of the Vegetation Units Recorded from the Island of Capo Passero (SE-Sicily)

Crithmo-Staticetea Br.-Bl. in Br.-Bl., Roussine and Nègre 1952

Crithmo-Staticetalia Molinier 1934

Crithmo-Staticion Molinier 1934

Crithmo maritimi-Limonietum virgati Pirone 1995

Limonietum hyblaei Bartolo, Brullo and Marcenò 1982

Salicomietea fruticosae Br-Bl. and R. Tx. ex A. Bolòs y Vayreda and O. Bolòs in A. Bolòs y Vayreda 1950

Salicornietalia fruticosae Br.-Bl. 1933

Arthrocnemion macrostachyi Rivas-Mart. and M. Costa 1984

Limonio virgati-Arthrocnemetum macrostachyi Biondi, Casavecchia and Guerra 2006

Suaedion brevifoliae Br.-Bl. and O. de Bolòs 1958

Halimiono portulacoidis-Suaedetumverae Molinier and Tallon 1970 corr. Géhu in Géhu and al. 1984

Saginetea maritimae Westhoff, Van Leeuwen and Adriani 1962

Frankenietalia pulverulentae Rivas-Mart. ex Castroviejo and Porta 1976

Frankenion pulverulentae Rivas-Mart. ex Castroviejo and Porta 1976

Polypogonetum subspathacei Gamisans 1992

Parapholido incurvae-Catapodietum balearici Rivas-Mart. et al. 1990 corr. Brullo and Giusso 2003

Senecio pygmaeus community

Mesembryanthemion crystallini Rivas-Mart., Wildpret, Del Arco, O. Rodríguez, Pérez de Paz, García Gallo, Acebes, T.E.

Díaz and Fernández-González 1993

Spergulario bocconei-Mesembryanthemetum nodiflori Costa in Costa et al. 1997

Ononido-Rosmarinetea Br.-Bl. in A. Bolòs y Vayreda 1950

Cisto-Micromerietalia julianae Oberd. 1954

Cisto cretici-Ericion manipuliflorae Horvatic 1958

Chamaeropo humilis-Sarcopoterietum spinosi Barbagallo, Brullo and Fagotto 1979

Quercetea ilicis Br.-Bl. ex A. Bolòs and O. de Bolòs in A. Bolòs y Vayreda 1950

Pistacio lentisci-Rhamnetalia alaterni Rivas-Mart. 1975

Oleo-Ceratonion siliquae Br.-Bl. ex Guinochet and Drouineau 1944

Pistacio lentisci-Chamaeropetum humilis Brullo and Marcenò 1985

Ammophiletea Br.-Bl. et Tx. ex Westhoff et al. 1946

Ammophiletalia Br.-Bl. et Tx. ex Westhoff et al. 1946

Ammophilion australis Br.-Bl. 1921

Medicagini marinae-Ammophiletum australis Br.-Bl. 1921 corr. Prieto and Diaz 1991

Crucianelletalia maritimae Sissing 1974

Crucianellion maritimae Rivas Goday and Rivas-Mart. 1958

Centaureo sphaerocephalae-Ononidetum ramosissimae Br.-Bl. and Frei in Frei 1937

Cakiletea maritimae Tx. and Preising in Tx. Ex Br.-Bl. and Tx. 1952

Atriplicetalia littoralis Sissingh in Westhoff et al. 1946

Atriplicion littoralis Nordhagen 1940

Salsolo-Cakiletum maritimae Costa and Mansanet 1981 corr. Rivas-Mart. et al. 1992

Helianthemetea guttati Rivas Goday and Rivas-Mart. 1963

Vulpietalia Pignatti 1953

Laguro ovati-Vulpion fasciculatae Géhu and Biondi 1994

Silene nicaensis and Senecio coronopifolius community

Stipo-Trachynietea distachyae S. Brullo in S. Brullo et al. 2001

Stipo-Bupleuretalia semicompositi S. Brullo in S. Brullo et al. 2001

Plantagini-Catapodion marini S. Brullo 1985

Stipellula capensis and Asteriscus aquaticus community

Phragmito-Magnocaricetea Klika in Klika and Novák 1941

Phragmitetalia Koch 1926

Phragmition Koch 1926

Typhetum domingensis Brullo, Minissale and Spampinato 1994 


\section{Appendix C}

Table A2. Phytosociological relevés from the Island of Capo Passero (SE Sicily)—shrub vegetation.

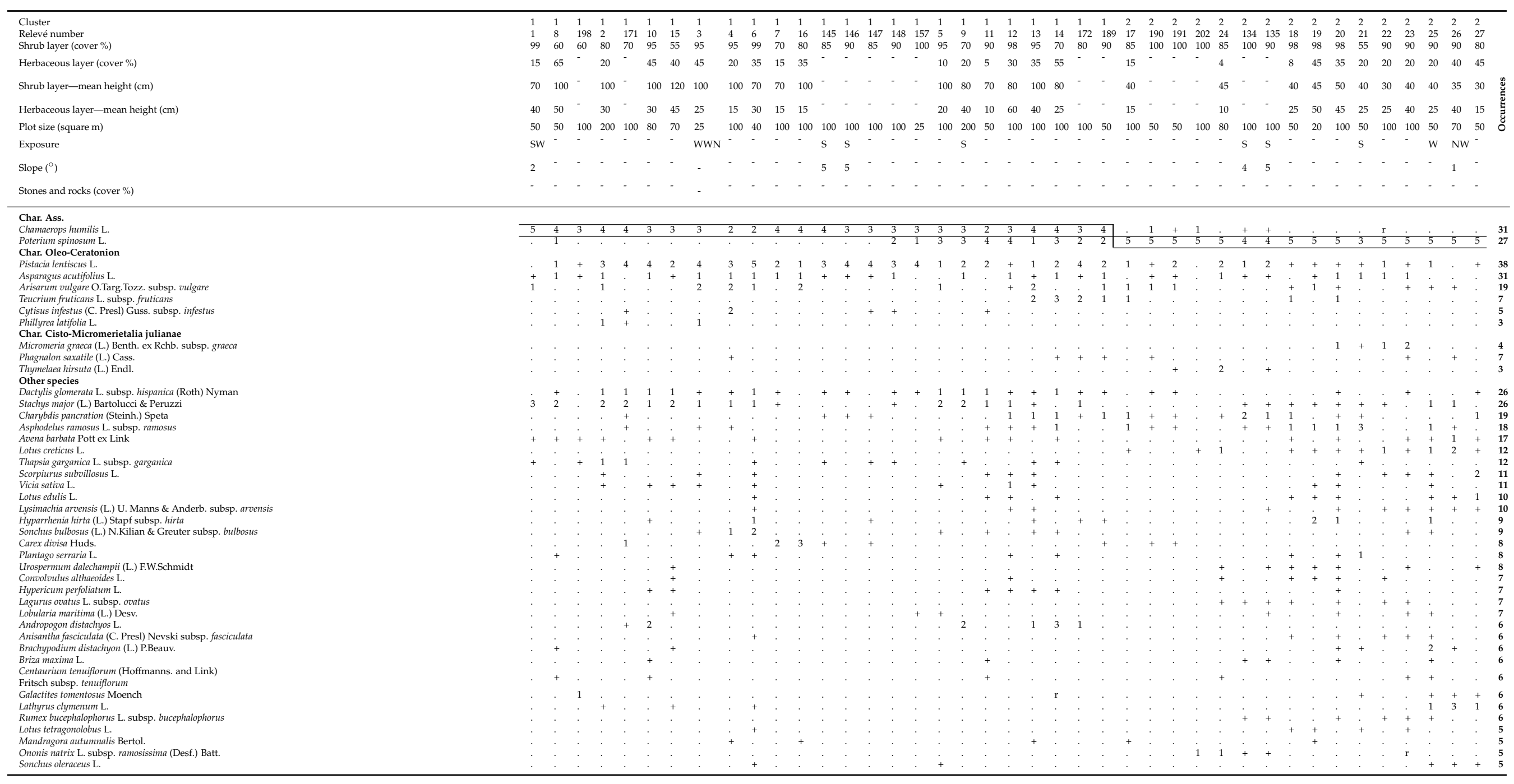


Table A2. Cont.

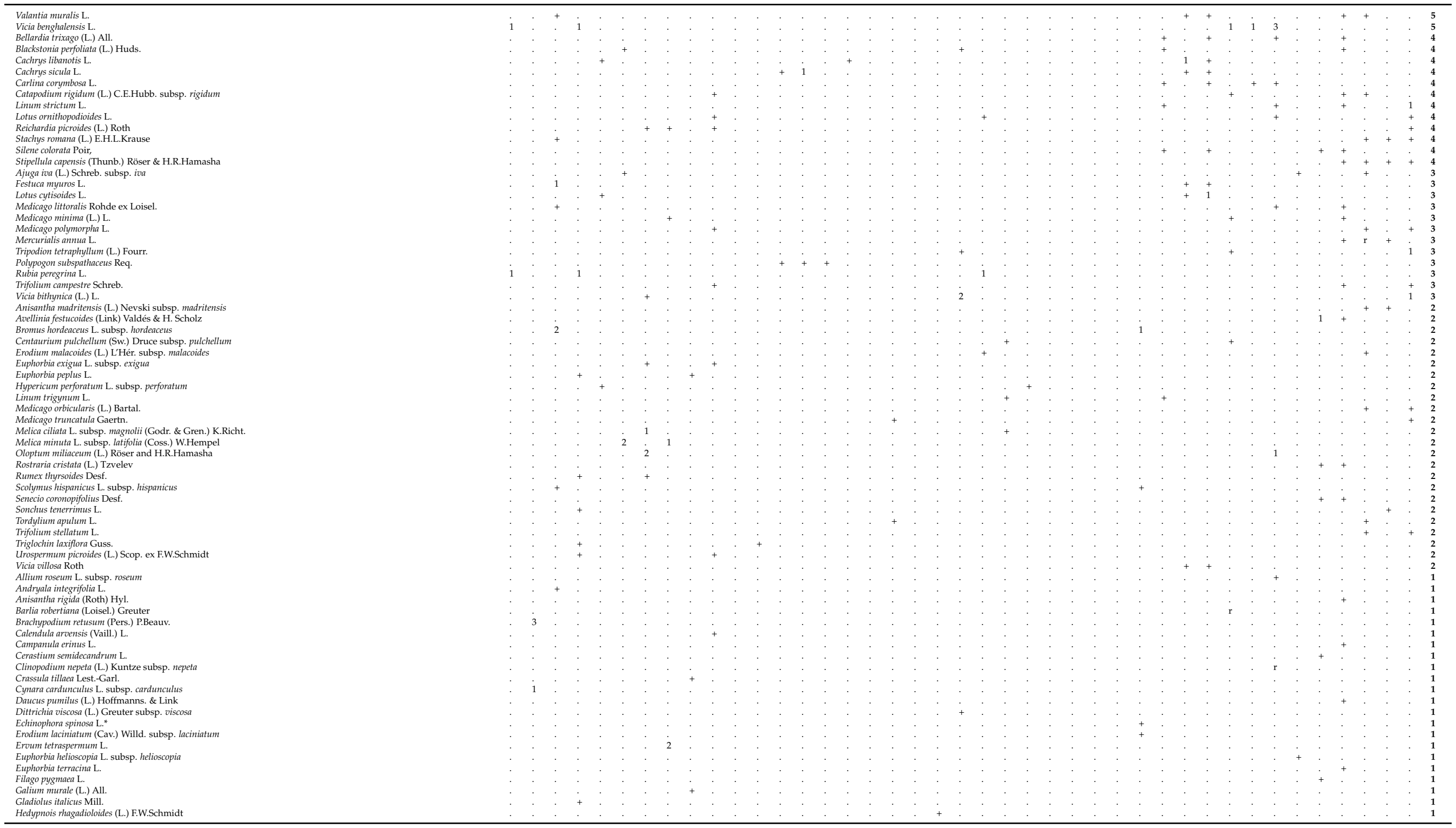


Table A2. Cont.

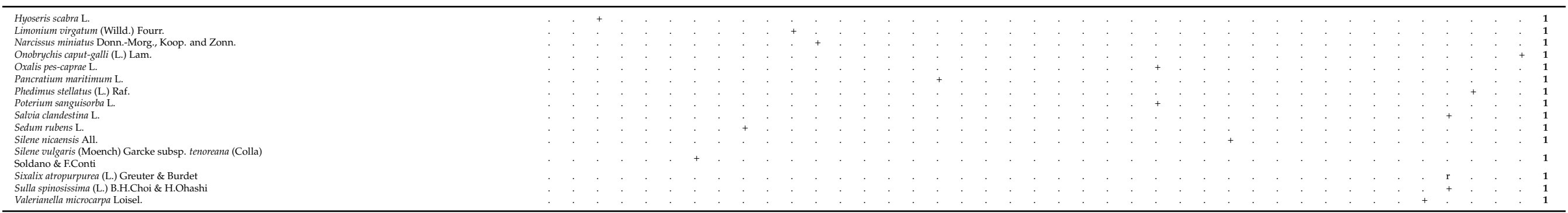

Table A3. Phytosociological relevés from the Island of Capo Passero (SE Sicily)—dry grasslands.

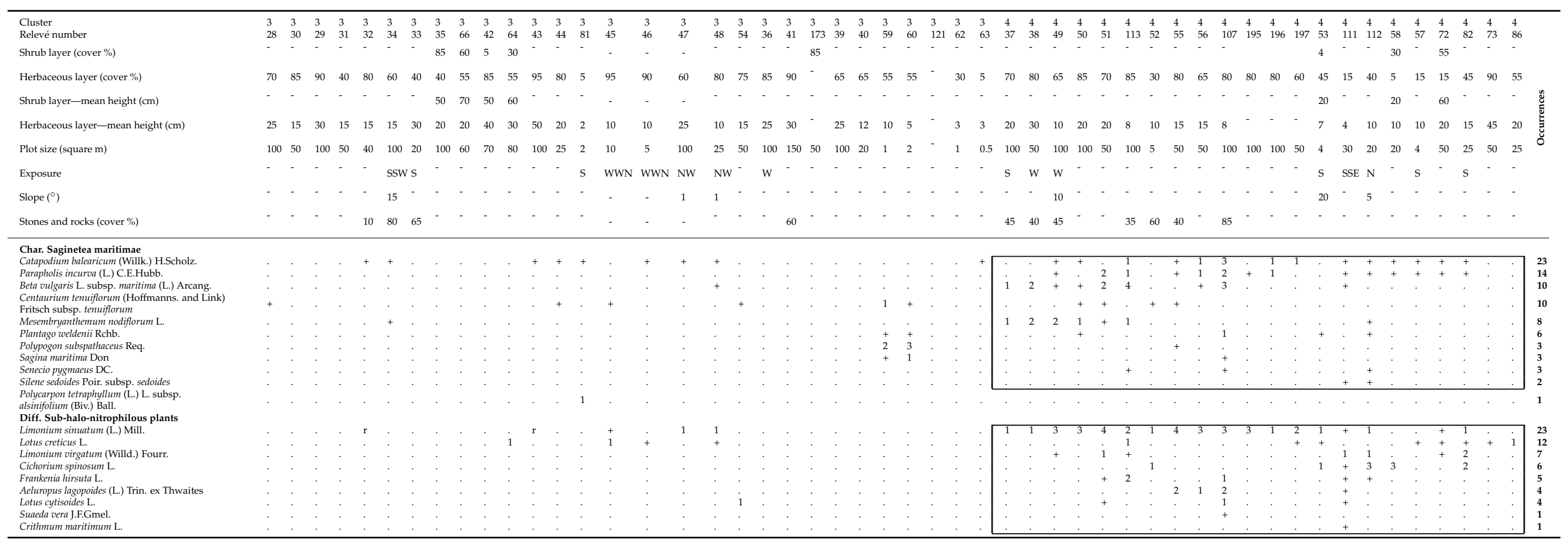


Table A3. Cont.

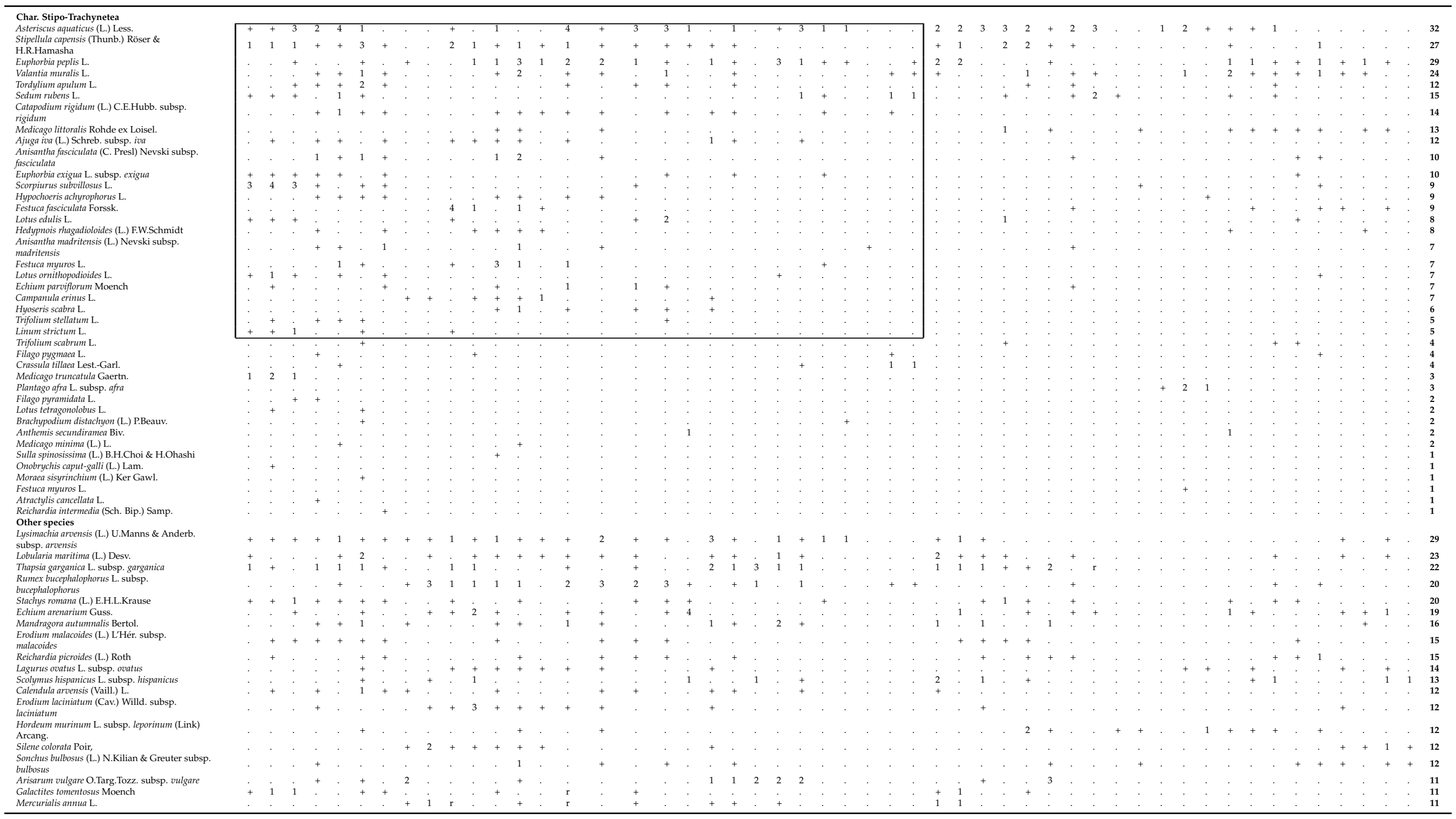


Table A3. Cont.

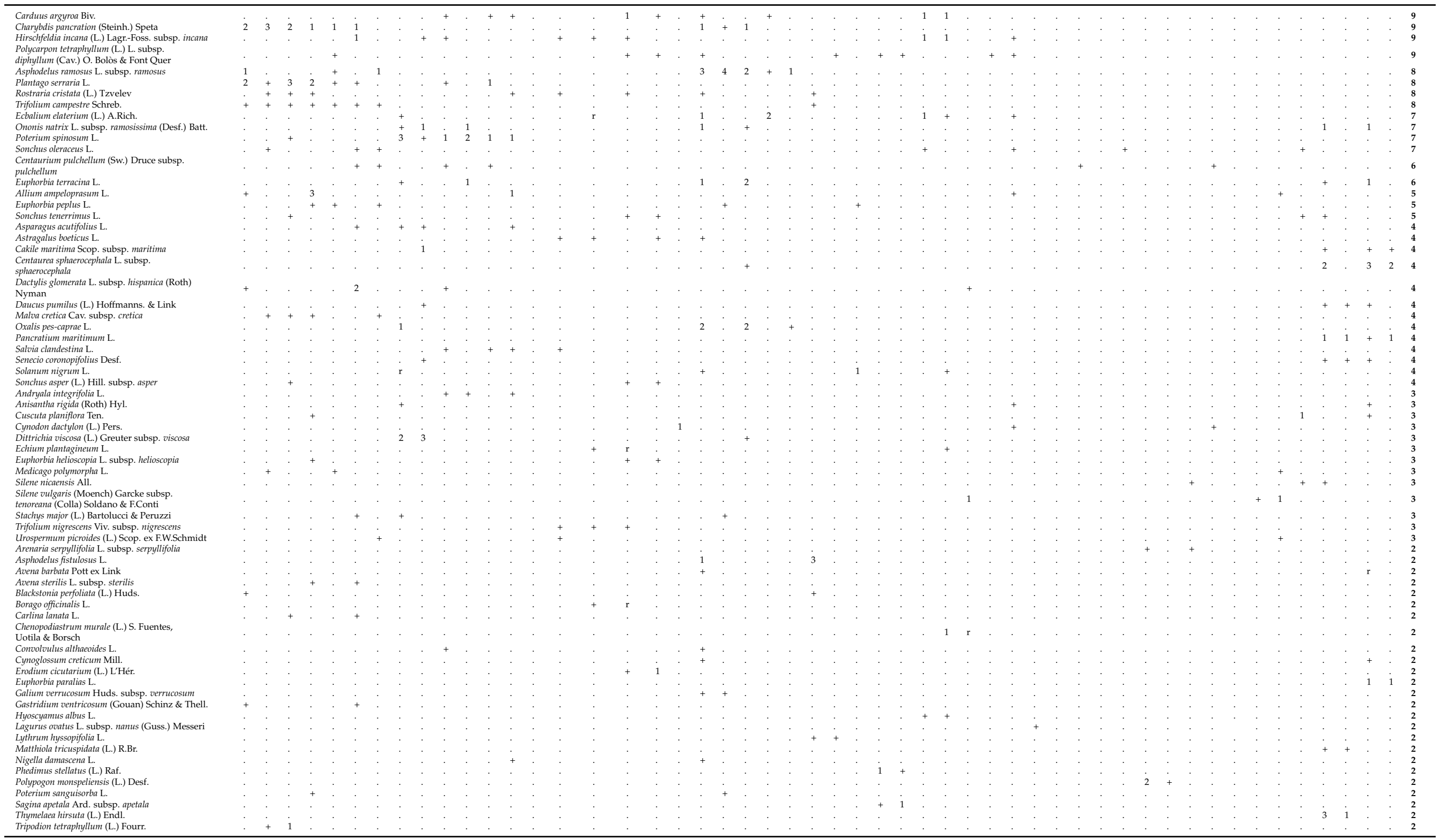


Table A3. Cont.

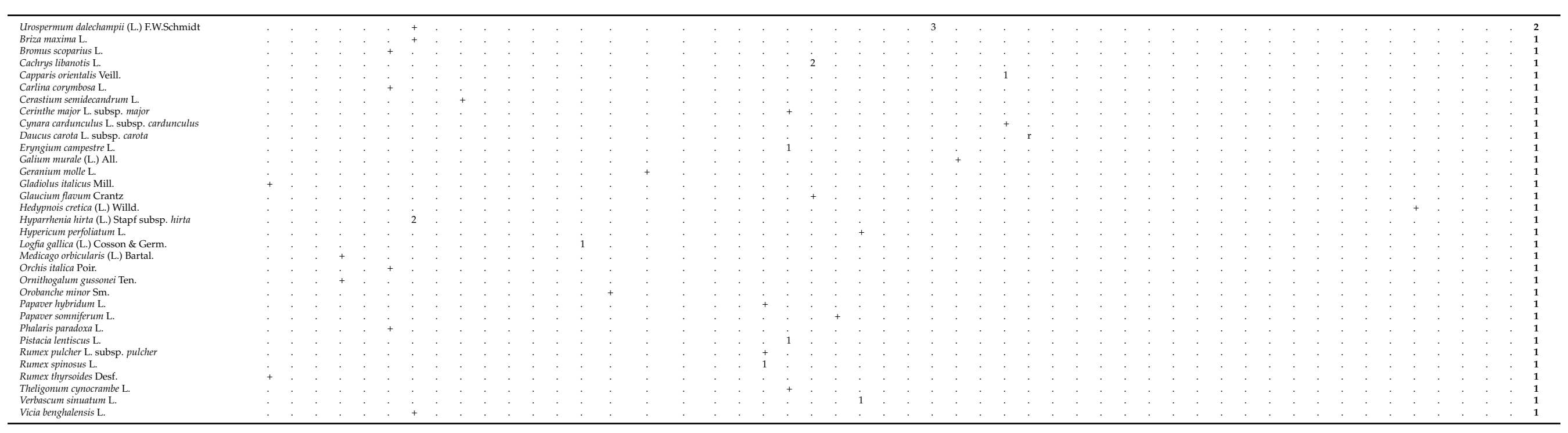

Table A4. Phytosociological relevés from the Island of Capo Passero (SE Sicily)—psammophilous vegetation.

\begin{tabular}{|c|c|c|c|c|c|c|c|c|c|c|c|c|c|c|c|c|c|c|c|c|c|c|c|c|c|c|c|c|c|c|c|c|c|c|c|c|c|}
\hline $\begin{array}{l}\text { Cluster } \\
\text { Relevé number } \\
\text { Shrub layer (cover \%) }\end{array}$ & $\begin{array}{l}5 \\
65 \\
-\end{array}$ & & $\begin{array}{l}5 \\
12 \\
75\end{array}$ & $\begin{array}{l}5 \\
67 \\
15\end{array}$ & $\begin{array}{l}5 \\
68 \\
40\end{array}$ & $\begin{array}{l}5 \\
70 \\
40\end{array}$ & $\begin{array}{l}5 \\
69 \\
70\end{array}$ & $\begin{array}{l}5 \\
71 \\
30\end{array}$ & $\begin{array}{l}5 \\
200 \\
80\end{array}$ & $\begin{array}{l}5 \\
201 \\
60\end{array}$ & $\begin{array}{c}5 \\
74 \\
-\end{array}$ & $\begin{array}{l}5 \\
75 \\
-\end{array}$ & $\begin{array}{l}5 \\
76 \\
30\end{array}$ & $\begin{array}{l}5 \\
77 \\
-\end{array}$ & $\begin{array}{l}5 \\
87 \\
45\end{array}$ & $\begin{array}{l}5 \\
17 \\
70\end{array}$ & $\begin{array}{l}5 \\
175 \\
65\end{array}$ & $\begin{array}{l}5 \\
195 \\
30\end{array}$ & $\begin{array}{l}5 \\
122 \\
90\end{array}$ & $\begin{array}{l}5 \\
17 \\
90\end{array}$ & $\begin{array}{l}5 \\
176 \\
70\end{array}$ & $\begin{array}{l}5 \\
125 \\
90\end{array}$ & $\begin{array}{l}5 \\
5 \\
5 \\
124 \\
85\end{array}$ & $\begin{array}{l}5 \\
178 \\
90\end{array}$ & $\begin{array}{l}6 \\
78 \\
15\end{array}$ & $\begin{array}{l}6 \\
179 \\
85\end{array}$ & $\begin{array}{l}6 \\
123 \\
90\end{array}$ & $\begin{array}{l}6 \\
79 \\
10\end{array}$ & $\begin{array}{l}6 \\
80 \\
10\end{array}$ & $\begin{array}{l}6 \\
85\end{array}$ & $\begin{array}{l}7 \\
83 \\
-\end{array}$ & $\begin{array}{l}7 \\
162 \\
70\end{array}$ & $\begin{array}{l}7 \\
84 \\
-\end{array}$ & & $\begin{array}{l}7 \\
15 \\
65\end{array}$ & $\begin{array}{l}7 \\
160 \\
75\end{array}$ & $\begin{array}{l}7 \\
161 \\
70\end{array}$ \\
\hline Herbaceous layer (cover \%) & 85 & - & - & 45 & 45 & 55 & 40 & 60 & 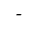 & - & 45 & 55 & 20 & 20 & & & & 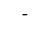 & - & 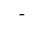 & - & & & - & 60 & & 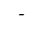 & 70 & 85 & 45 & 40 & - & 10 & . & 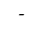 & 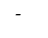 & 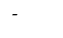 \\
\hline Shrub layer-mean height $(\mathrm{cm})$ & & & & 50 & 50 & 55 & 60 & 45 & & & & & 45 & & & & & & & & & & & - & 40 & & & 40 & 40 & - & & & & - & & & \\
\hline Herbaceous layer-mean height (cm) & 10 & - & - & 25 & 35 & 15 & 20 & 40 & - & - & 5 & 5 & 20 & 15 & 35 & - & - & - & - & - & 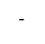 & - & - & - & 60 & - & - & 90 & 80 & 70 & 30 & - & 35 & . & - & - & - \\
\hline $\begin{array}{l}\text { Plot size (square m) } \\
\text { Exposure }\end{array}$ & 4 & 4 & 4 & 30 & 100 & 100 & $\begin{array}{l}50 \\
-\end{array}$ & 100 & $\begin{array}{l}50 \\
\mathrm{~s}\end{array}$ & $\begin{array}{l}100 \\
\mathrm{~s}\end{array}$ & $\stackrel{2}{2}$ & $\begin{array}{l}2 \\
\mathrm{~s}\end{array}$ & 20 & $\begin{array}{l}20 \\
\mathrm{E}\end{array}$ & 30 & ${ }^{20}$ & 20 & 100 & 100 & 20 & 20 & 100 & 0100 & 20 & 20 & 20 & ${ }_{-}^{25}$ & 50 & ${ }^{50}$ & ${ }^{20}$ & 30 & 10 & $\begin{array}{l}60 \\
-\end{array}$ & 10 & $\begin{array}{l}10 \\
-\end{array}$ & 10 & 10 \\
\hline Slope $\left(^{\circ}\right)$ & - & - & - & - & - & - & - & - & 10 & 20 & - & - & - & 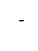 & - & - & - & - & - & - & - & - & - & - & - & - & - & - & 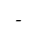 & - & - & - & - & - & - & - & - \\
\hline \multirow{2}{*}{$\begin{array}{l}\text { Char. Ass. } \\
\text { Ononis antrix L. subsp. ramosissima (Desf.) Batt. } \\
\text { Calamagrostis arenaria (L.) Roth subsp. arundinacea (Husn.) Banfi, } \\
\text { Galasso \& Bartolucci } \\
\text { Cakile maritima Scop. subsp. maritima }\end{array}$} & + & + & + & 2 & 4 & 4 & 4 & 3 & 2 & 3 & + & + & 3 & + & 2 & 3 & 3 & $\cdot$ & 4 & 4 & 4 & 4 & 3 & 3 & 2 & 2 & 3 & 1 & 1 & . & & . & . & . & . & . & . \\
\hline & . & . & . & . & . & . & . & . & . & . & . & . & . & . & . & . & 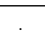 & 1 & . & . & 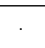 & 1 & 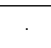 & . & 5 & 4 & 3 & 4 & 5 & 3 & & & + & & & & .9 \\
\hline
\end{tabular}


Table A4. Cont.

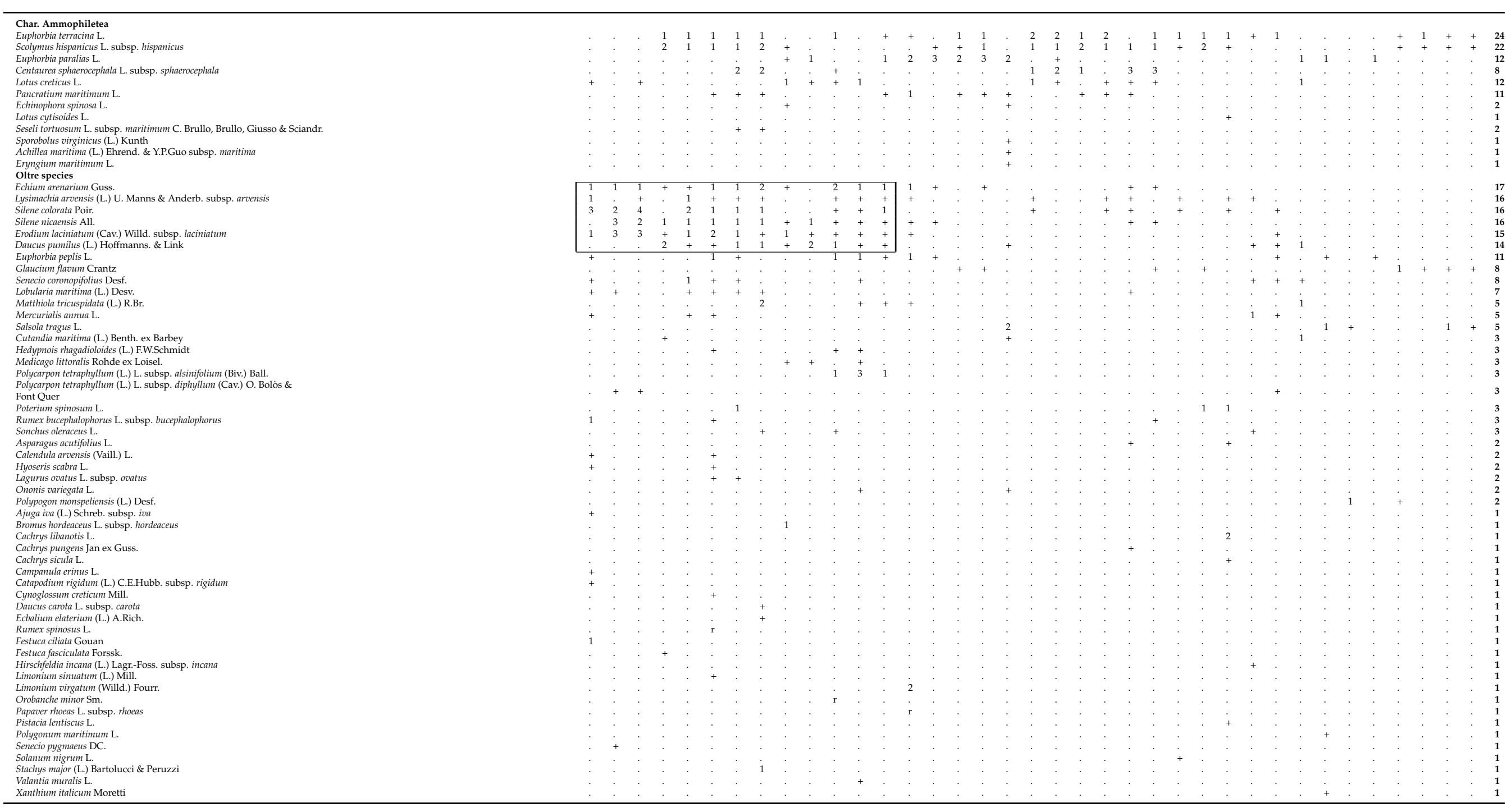


Table A5. Phytosociological relevés from the Island of Capo Passero (SE Sicily)—rocky coast vegetation.

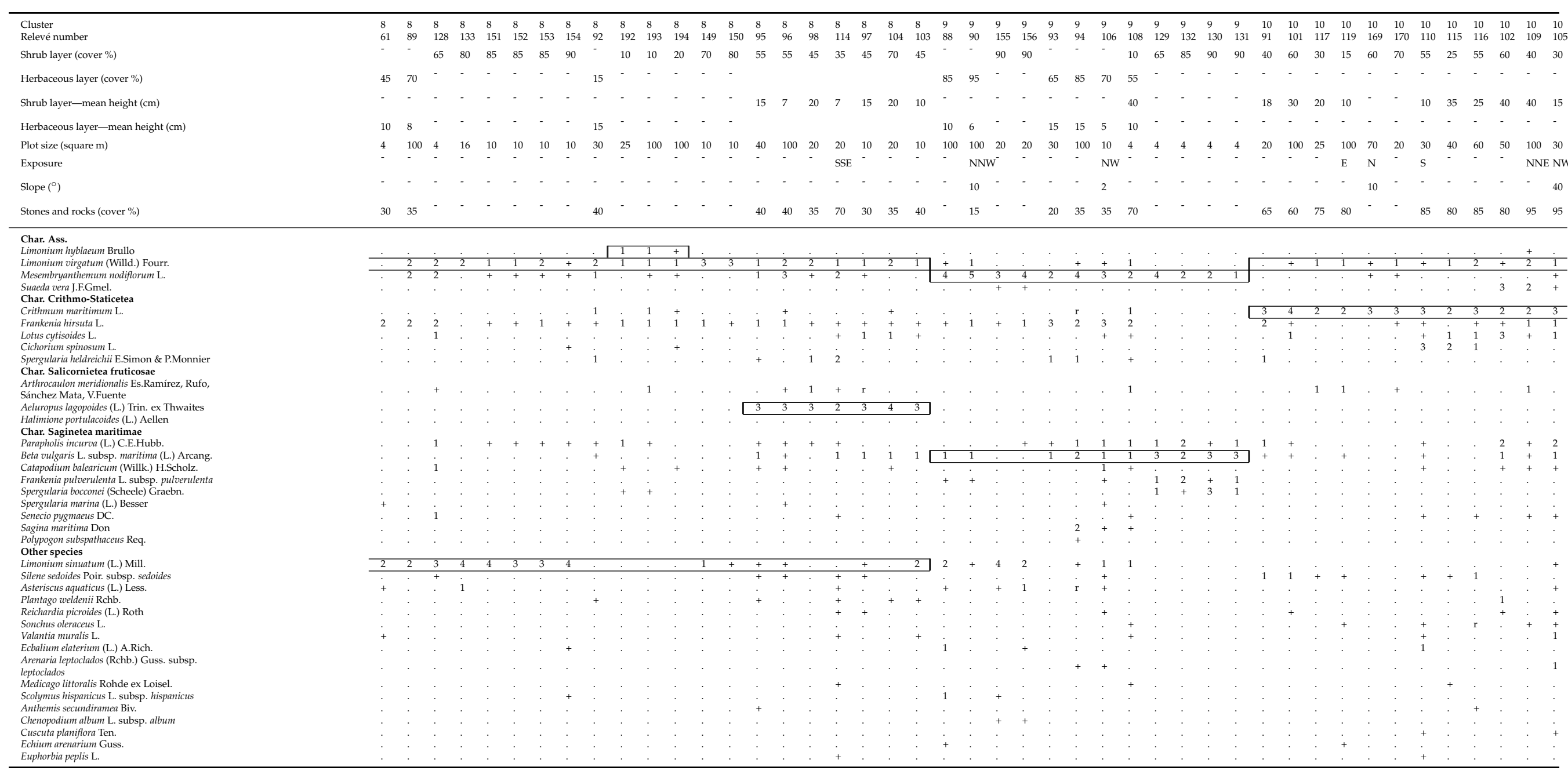


Table A5. Cont.

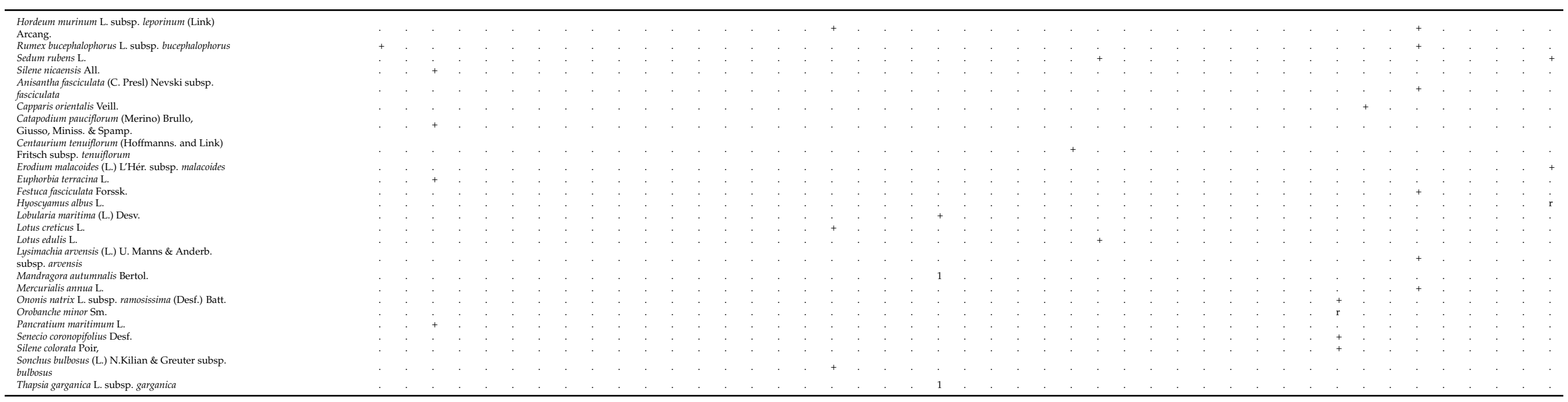

Table A6. Phytosociological relevés from the Island of Capo Passero (SE Sicily)—rocky coast vegetation.

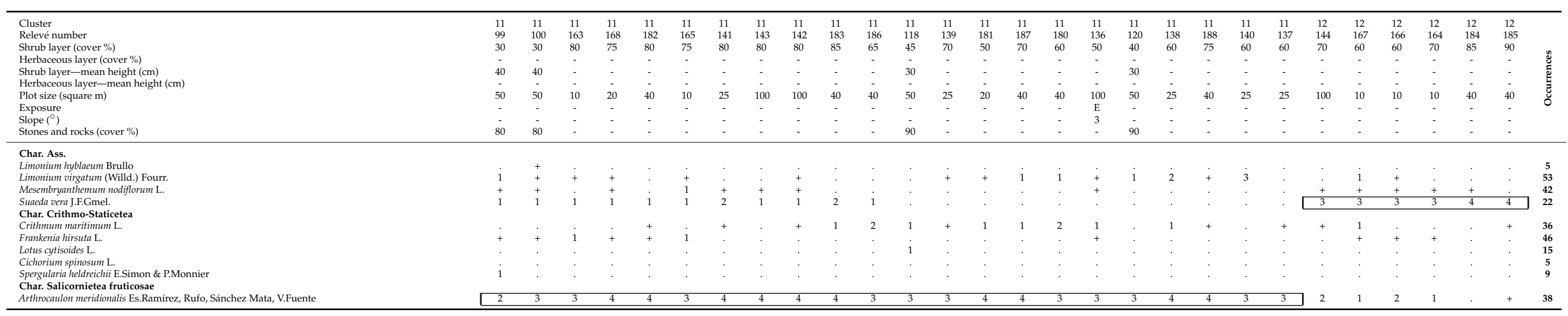


Table A6. Cont.

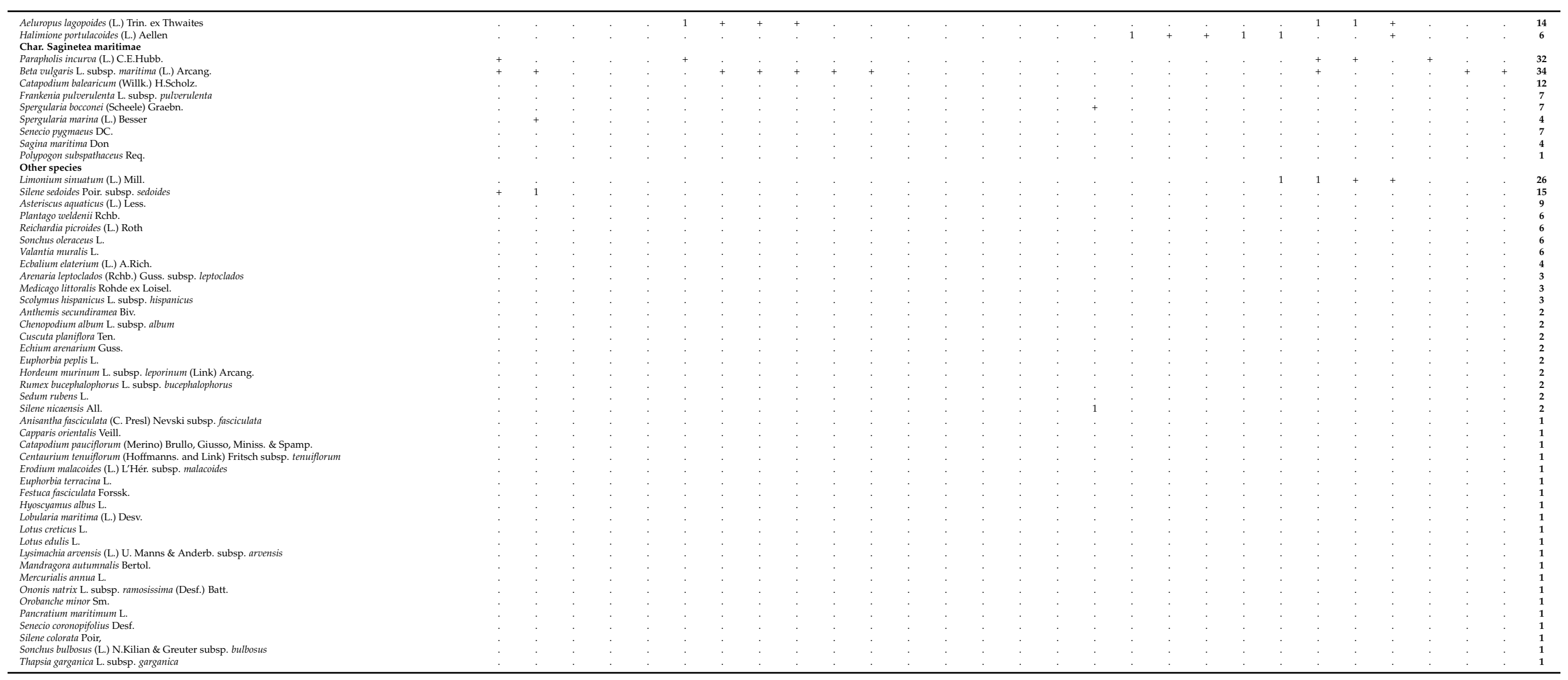

\section{Dates of relevés}

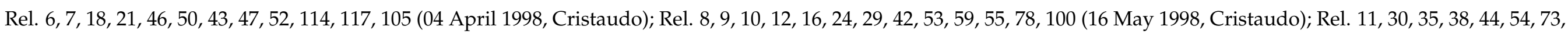

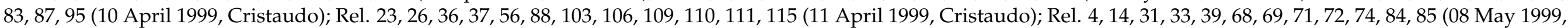

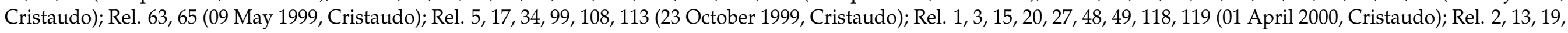

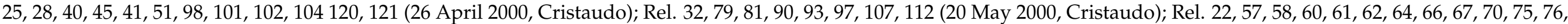

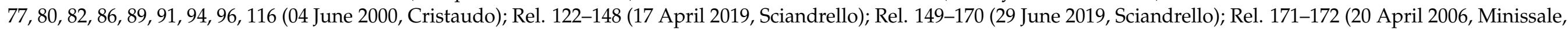
Sciandrello, Spampinato); Rel. 173-191 (03 February 2017, Sciandrello); Rel. 192-202 (Pirola 1959). 


\section{Appendix D}
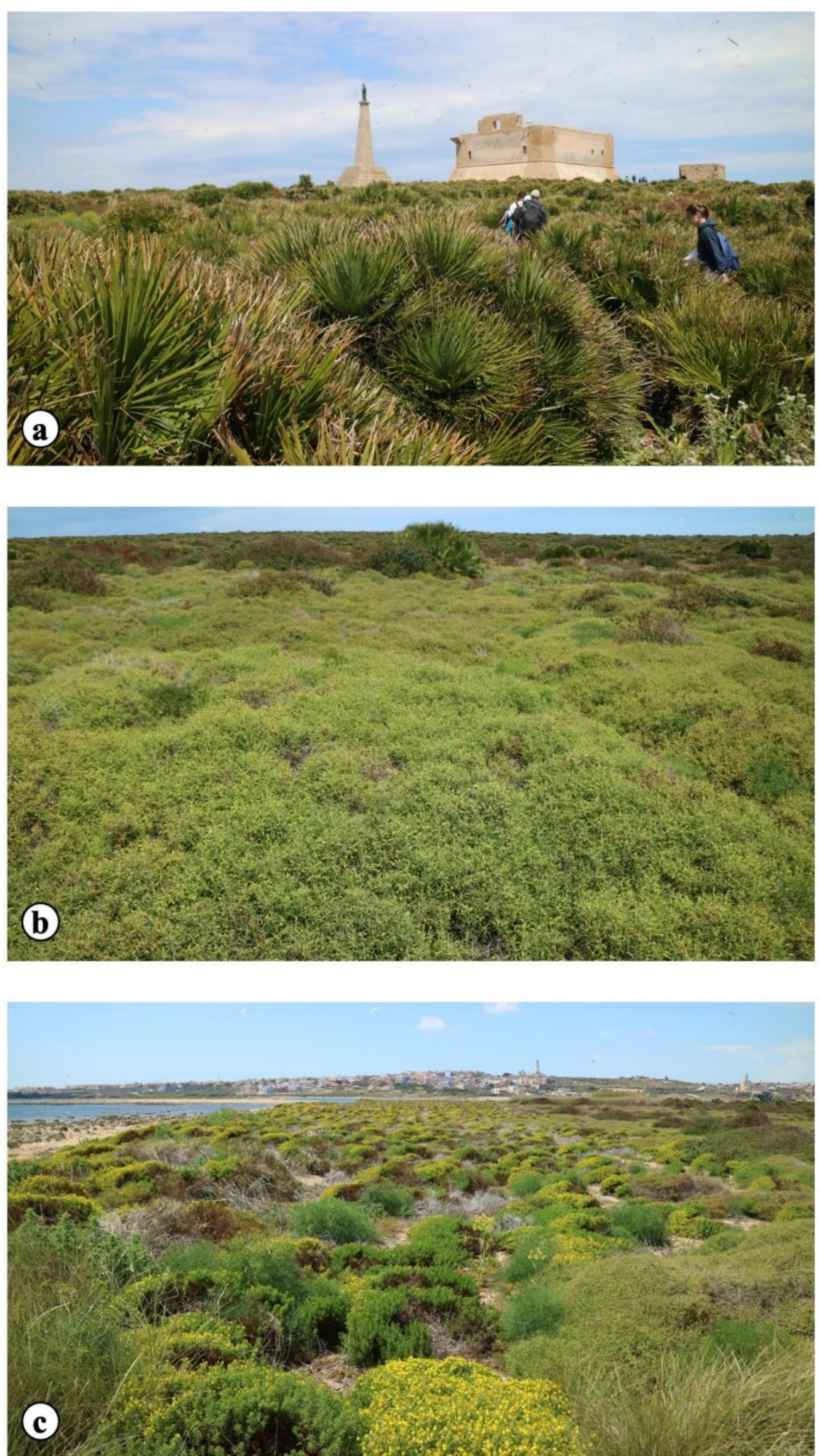

Figure A1. Photo plate illustrating different habitat types on the Island of Capo Passero: (a) Chamaerops humilis maquis (Pistacio lentisci-Chamaeropetum humilis; (b) Poterium spinosum garrigue (Chamaeropo humilis-Sarcopoterietum spinosi); (c) Stable dunes with Ononis ramosissima (Centaureo sphaerocephalae-Ononidetum ramosissimae). 

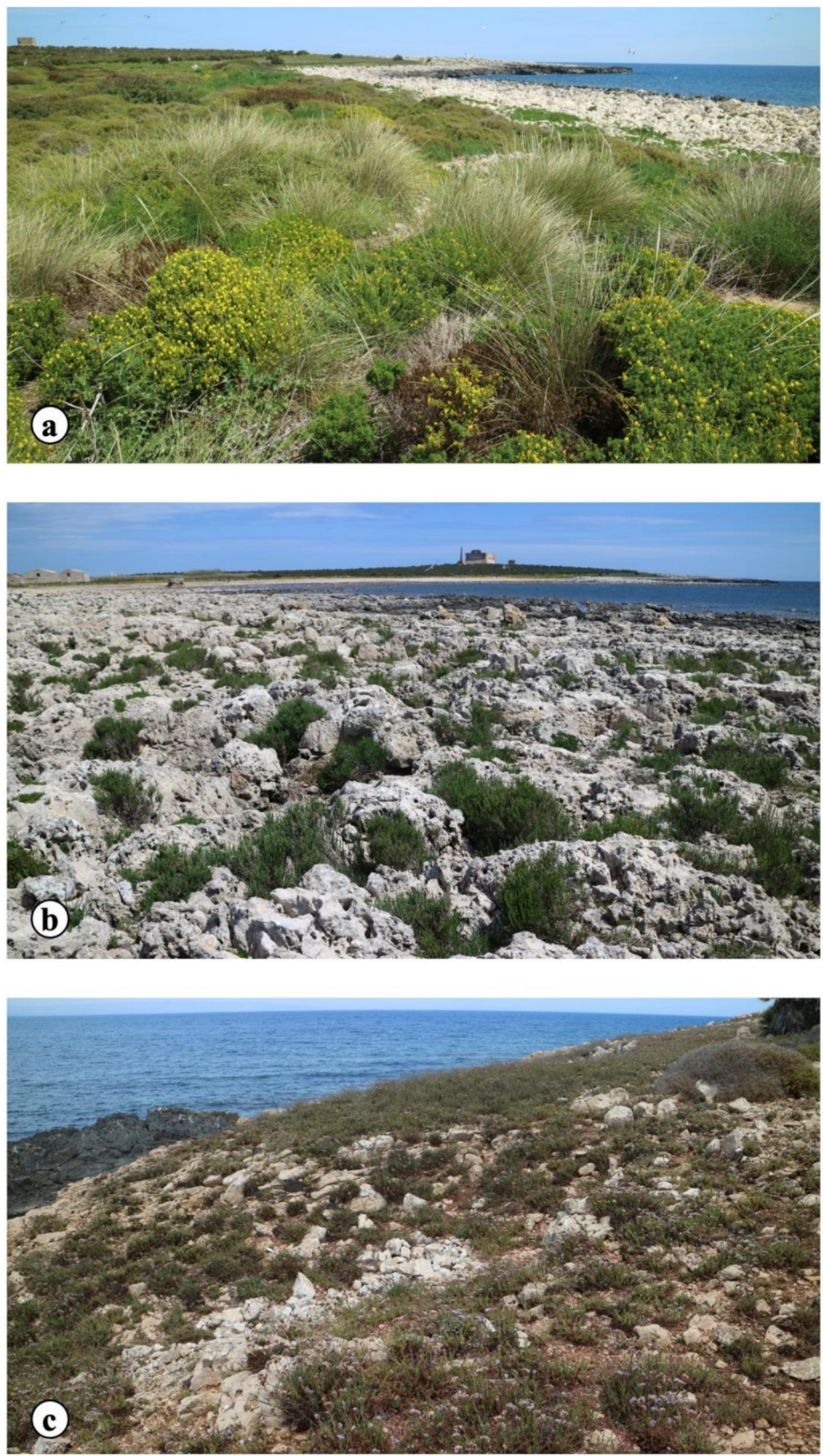

Figure A2. Photo plate illustrating different habitat types on the Island of Capo Passero: (a) last strips of vegetation with Calamagrostis arundinacea (Medicagini marinae-Ammophiletum australis) mixed with Ononis ramosissima; (b) rocky coast vegetation (Limonio virgati-Arthrocnemetum macrostachyi); (c) Rocky coast vegetation (Limonietum hyblaei, Crithmo maritimi-Limonietum virgati). 


\section{References}

1. Whittaker, R.J.; Fernández-Palacios, J.M. Island Biogeography, Ecology, Evolution, and Conservation; Oxford University Press: Oxford, UK, 2018; p. 416.

2. Bergmeier, E.; Dimopoulos, P. The vegetation of islets in the Aegean and the relation between the occurrence of islet specialists, island size, and grazing. Phytocoenologia 2003, 33, 447-474. [CrossRef]

3. Foggi, B.; Guidi, T.; Capecchi, M.; Baldini, R.M.; Grigioni, A. Biological flora of the Tuscan Archipelago islets (Tyrrhenian Sea). Webbia 2009, 64, 23-45. [CrossRef]

4. Fois, M.; Fenu, G.; Bacchetta, G. Global analyses underrate part of the story: Finding applicable results for the conservation planning of small Sardinian islets' flora. Biodivers. Conserv. 2016, 25, 1091-1106. [CrossRef]

5. Cascio, P.L.; Pasta, S. Floristic and ecological remarks on the islet Formica di Burano (Tuscan Archipelago, Tyrrhenian Sea). Atti Soc. Tosc. Sci. Nat. Mem. Ser. B 2011, 116, 45-48.

6. Médail, F.; Vidal, É. Organisation de la richesse et de la composition floristiques d'îles de la Méditerranée occidentale (sud-est de la France). Can. J. Bot. 1998, 76, 321-331.

7. Panitsa, M.; Tzanoudakis, D.; Triantis, K.A.; Sfenthourakis, S. Patterns of species richness on very small islands: The plants of the Aegean archipelago. J. Biogeogr. 2006, 33, 1223-1234. [CrossRef]

8. Rita, J.; Bibiloni, G. The flora of the islets of the Balearic Islands. In Proceedings of the 2nd Botanical Conference in Menorca, Islands and plants: Preservation and understanding of flora on Mediterranean Islands, Es Mercadal, Spain, 26-30 April 2011; pp. 309-322.

9. Véla, E.; Saatkamp, A.; Pavon, D. Flora of Habibas Islands (N-W Algeria): Richness, persistence ad taxonomy. In Proceedings of the 2nd Botanical Conference in Menorca, Islands and plants: Preservation and understanding of flora on Mediterranean Islands, Es Mercadal, Spain, 26-30 April 2011; pp. 271-287.

10. Guarino, R.; Pasta, S. Sicily: The island that didn't know to be an archipelago. Ber. Reinhold Tüxen Gesellschaft 2018, 30, 133-148.

11. Pasta, S.; La Mantia, T. Plant species richness, biogeographic and conservation interest of the vascular flora of the satellite islands of Sicily: Patterns, driving forces and threats. In Proceedings of the 2nd Botanical Conference in Menorca, Islands and plants: Preservation and understanding of flora on Mediterranean Islands, Es Mercadal, Spain, 26-30 April 2011; pp. $201-240$.

12. Brullo, S.; Di Martino, A. Vegetazione dell'Isola Grande dello Stagnone (Marsala). Boll. Studi Inform. Giard. Bot. Palermo 1974, 26, $15-62$.

13. Caldarella, O.; La Rosa, A.; Pasta, S.; Di Dio, V. La flora vascolare della Riserva Naturale Orientata, Isola delle Femmine (Sicilia nord-occidentale): Aggiornamento della check-list e commento del turnover. Nat. Sicil. Ser. 2010, 34, 421-476.

14. Catanzaro, F. Contributo alla flora dell'Isola di S. Pantaleo (Mozia) nelle Egadi (Sicilia occidentale). Atti Soc. Tosc. Sci. Nat. Mem. Ser. B 1992, 98, 239-247.

15. Di Martino, A.; Perrone, C. Flora delle isole dello Stagnone (Marsala): I. Isola Grande. Lav. Ist. Bot. Giard. Colon. Palermo 1970, 24, 109-166.

16. Di Martino, A.; Perrone, C. Flora delle isole dello Stagnone (Marsala): II. Isole di S. Pantaleo e S. Maria. Lav. Ist. Bot. Giard. Colon. Palermo 1974, 25, 71-102.

17. Di Martino, A.; Trapani, S. Flora e vegetazione dell'Isola delle Femmine. Lav. Ist. Bot. Giard. Colon. Palermo 1964, 20, 121-159.

18. Cascio, P.L.; Pasta, S. Bio-ecological survey on the vascular flora of the satellite islets of the Aeolian Archipelago (south-eastern Tyrrhenian Sea, Italy). In Life on Islands: Biodiversity in Sicily and Surrounding Islands; Massa, B., La Mantia, T., Badalamenti, E., Carapezza, A., Cascio, P.L., Troia, A., Eds.; Edizioni Danaus: Palermo, Italy, 2020; pp. 21-46.

19. Cascio, P.L.; Pasta, S. Lampione, a paradigmatic case of Mediterranean island biodiversity. Biodiv. J. 2012, 3, 311-330.

20. Minissale, P.; Sciandrello, S. Flora and habitats of Vendicari Islet (Isola di Vendicari) in South East Sicily. Nat. Croat. 2017, 26, 1-16. [CrossRef]

21. Minissale, P.; Sciandrello, S.; Spampinato, G. Analisi della biodiversita' vegetale e relativa cartografia della Riserva Naturale Orientata Isola Bella e del territorio circostante (Taormina, ME, Sicilia). Quad. Bot. Ambient. Appl. 2005, 16, 175-208.

22. Musmarra, A. Florula Delle Isole Dei Ciclopi, Scuola Tip; dell'Orfanotrofio maschile: Amatrice, Italy, $1941 ;$ p. 57.

23. Pasta, S.; Appendice, I. Elenco aggiornato della flora vascolare. In Storia Naturale Delle Isole Pelagie; Corti, C., Cascio, P.L., Masseti, M., Pasta, S., Eds.; L'Epos: Palermo, Italy, 2002; pp. 135-148.

24. Pasta, S. La conservazione delle emergenze botaniche nell'area costiera siciliana: Il caso della R.N.O. Isole dello Stagnone di Marsala (Trapani, Sicilia occidentale). Nat. Sicil. Ser. 2004, 28, 243-263.

25. Pasta, S.; Sciberras, A.; Sciberras, J.; Scuderi, L. Analysis of the vascular flora of four satellite islets of the Egadi Archipelago (W Sicily), with some notes on their vegetation and fauna. Biodiv. J. 2014, 5, 39-54.

26. Sciandrello, S.; Minissale, P.; Sturiale, G. Plant communities supported by the geological setting: The case history of the Isole dei Ciclopi (east Sicily). Lazaroa 2017, 38, 27-51. [CrossRef]

27. Siracusa, G. Florula delle Isole dei Ciclopi (Sicilia orientale). Boll. Accad. Gioenia Sci. Nat. Ser. 1996, 28, $219-238$.

28. Guarino, R.; Cristaudo, A.; Minissale, P.; Sciandrello, S.; Pasta, S. Life forms and seed dispersal strategies suggest disturbancedriven vegetation changes on a Mediterranean islet 350 years after its first exploration. In Proceedings of the Abstract Book of the 61st Annual Symposium of the International Association for Vegetation Science (IAVS): Natural Ecosystems as Benchmarks for Vegetation Science, Bozeman, MT, USA, 22-27 July 2018; p. 92. 
29. Pasta, S. The oldest plant list of a Mediterranean islet ever published? John Ray at Island of Capo Passero (Sicily, May 8-10, 1664). Taxon submitted (accessed on 12 March 2021).

30. Albo, G. L'Isola di Capo Passero e la sua vegetazione. Nat. Sicil. 1919, 23, 179-201.

31. Albo, G. La flora e la vegetazione delle isole intorno al Capo Pachino. Boll. Ist. Bot. Univ. Catania Ser. 1959, 1, 88-108.

32. Béguinot, A. Ricerche sulla distribuzione geografica e sul polimorfismo della Chamaerops humilis L. spontanea, coltivata, fossile (con la collaborazione di A. Zagolin). Boll. Ist. Bot. R. Univ. Sassari 1922, 6, 118.

33. Pirola, A. Contributo alla conoscenza della vegetazione dell'Isola of Capo Passero (Sicilia sud-orientale). Boll. Ist. Bot. Univ. Catania Ser. 1960, 3, 65-75.

34. Pirola, A. Carta della vegetazione dell'Isola di Capo Passero. Atti Ist. Bot. Univ. Lab. Critt. Pavia Ser. 1965, 1, 105-109.

35. Galletti, I. La vegetazione. In L'Isola di Capo Passero; Ediprint: Palermo, Italy, 1988; pp. 17-27.

36. Camatta, V.; Chiesura Lorenzoni, F.; Lorenzoni, G.G. La presenza contemporanea di specie a diverso areale nella zona di Porto Palo e Capo Passero (Sicilia sud-orientale) indice di una possibile interpretazione della mediterraneità. In $A A$. VV. Atti del $3^{\circ}$ Colloquio: Approcci Metodologici per la Definizione Dell'ambiente Fisico e Biologico Mediterraneo; Orantes: Lecce, Italy, 1990; pp. 145-190.

37. Cristaudo, A.; Maugeri, G. Flora vascolare dell'Isola Capo Passero (Sicilia sud-orientale). Inform. Bot. Ital. $2005,37,328-329$.

38. Cristaudo, A.; Margani, I. Specie nuove o interessanti per la Flora Siciliana. Inform. Bot. Ital. 2006, 37, 1153-1159.

39. Pignatti, S.; Ellenberg, H.; Pietrosanti, S. Ecograms for phytosociological tables based on Ellenberg's Zeigerwerte. Ann. Bot. Roma 1996, 54, 5-14.

40. Orsenigo, S.; Fenu, G.; Gargano, D.; Montagnani, C.; Abeli, T.; Alessandrini, A.; Bacchetta, G.; Bartolucci, F.; Carta, A.; Castello, M.; et al. Red list of threatened vascular plants in Italy. Plant Biosyst. 2021, 155, 310-335. [CrossRef]

41. Bartolo, G.; Brullo, S.; Marcenò, C. La vegetazione costiera della Sicilia sud-orientale. CNR Collana Programma Finalizzato "Promozione Qualità Ambientale" 1982, AQ/1/226.

42. Brullo, S.; Brullo, C.; Cambria, S.; Giusso del Galdo, G. Rocky coast vegetation. In The Vegetation of Maltese Islands; Brullo, S., Brullo, C., Cambria, S., del Galdo, G.G., Eds.; Springer: Berlin/Heidelberg, Germany, 2020.

43. Bartolo, G.; Brullo, S. La classe Crithmo-Limonietea in Sicilia. Boll. Accad. Gioenia Sci. Nat. Ser. 1993, $26,5-47$.

44. Brullo, C.; Minissale, P.; Sciandrello, S.; Spampinato, G. Phytogeographic survey on the endemic vascular flora of the Hyblaean territory. Acta Bot. Gallica 2011, 158, 617-631. [CrossRef]

45. Brullo, S. Taxonomic and nomenclatural notes on the genus Limonium in Sicily. Bot. Notiser. 1980, 133, $281-293$.

46. Brullo, S.; Pavone, P. Chromosome numbers in the sicilian species of Limonium Miller (Plumbaginaceae). Anales Jard. Bot. Madr. 1981, 37, 535-555.

47. Orsenigo, S.; Montagnani, C.; Fenu, G.; Gargano, D.; Peruzzi, L.; Abeli, T.; Alessandrini, A.; Bacchetta, G.; Bartolucci, F.; Bovio, M.; et al. Red Listing plants under full national responsibility: Extinction risk and threats in the vascular flora endemic to Italy. Biol. Conserv. 2018, 224, 213-222. [CrossRef]

48. Minissale, P.; Santo, A.; Sciandrello, S. Analisi geobotanica del SIC: Capo Murro di Porco, Penisola della Maddalena e Grotta Pellegrino (Siracusa, Sicilia). Fitosociologia 2011, 48, 77-98.

49. Gargano, D.; Fenu, G.; Medagli, P.; Sciandrello, S.; Bernardo, L. The status of Sarcopoterium spinosum (Rosaceae) at the western periphery of its range: Ecological constraints lead to conservation concerns. Isr. J. Plant Sci. 2007, 55, 1-13. [CrossRef]

50. Conti, F.; Manzi, A.; Pedrotti, F. Liste Rosse Regionali delle Piante d'Italia; Società Botanica Italiana e Associazione Italiana per il World Wildlife Fund: Camerino, Macerata, Italy, 1997; p. 104.

51. Bergmeier, E.; Dimopoulos, P. Chances and Limits of Floristic Island Inventories: The Dionysades Group (South Aegean, Greece) Re-visited. Phyton Horn 2001, 41, 277-293.

52. MacArthur, R.H.; Wilson, E.O. The Theory of Island Biogeography; Princeton University Press: Princeton, NJ, USA, $1967 ;$ p. 203.

53. Brullo, S.; Gianguzzi, L.; La Mantia, A.; Siracusa, G. La classe Quercetea ilicis in Sicilia. Boll. Acc. Gioenia Sci. Nat. Ser. 4 2009, 41 , 1-124.

54. Brullo, S.; Marcenò, C. Contributo alla conoscenza della classe Quercetea ilicis in Sicilia. Not. Fitosoc. 1985, 19, 183-229.

55. Gianguzzi, L.; La Mantia, A. Contributo alla conoscenza della vegetazione e del paesaggio vegetale della Riserva Naturale Monte Cofano (Sicilia occidentale). Fitosociologia 2008, 45, 3-55.

56. Brullo, S.; Del Galdo, G.G.; Siracusa, G.; Spampinato, G. Considerazioni fitogeografiche sulla vegetazione psammofila dei litorali italiani. Biogeographia 2001, 22, 93-137.

57. Biondi, E.; Casavecchia, S.; Guerra, V. Analysis of vegetation diversity in relation to the geomorphological characteristics in the Salento coasts (Apulia-Italy). Fitosociologia 2006, 43, 25-38.

58. Sciandrello, S. Coastal saltmarsh vegetation in Sicily (Italy): Phytosociological insights and plant diversity. Plant Biosyst. 2020, 154, 860-876. [CrossRef]

59. Bertacchi, A.; Lombardi, T. Diachronic analysis (1954-2010) of transformations of the dune habitat in a stretch of the Northern Tyrrhenian Coast (Italy). Plant Biosyst. 2013, 148, 227-236. [CrossRef]

60. Díez-Garretas, B.; Comino, O.; Pereña, J.; Asensi, A. Spatio-temporal changes (1956-2013) of coastal ecosystems in Southern Iberian Peninsula (Spain). Medit. Bot. 2019, 40, 111-119.

61. Minissale, P.; Sciandrello, S. A relict wood of Juniperus turbinata Guss. (Cupressaceae) in Sicily. Ecological features and conservation perspectives. Plant Biosyst. 2013, 147, 145-157. [CrossRef] 
62. Sciandrello, S.; Tomaselli, G.; Minissale, P. The role of natural vegetation in the analysis of the spatio-temporal changes of coastal dune system: A case study in Sicily. J. Coast. Conserv. 2015, 19, 199-212. [CrossRef]

63. Tomaselli, V.; Tenerelli, P.; Sciandrello, S. Mapping and quantifying habitat fragmentation in small coastal areas: A case study of three protected wetlands in Apulia (Italy). Environ. Monit. Assess. 2012, 184, 693-713. [CrossRef]

64. Carbone, S.; Lentini, F.; Pistorio, A. Il Geosito: Calcari a Rudiste e Coralli del Cretacico superiore di Capo Passero (Monti Iblei, Sicilia SE). Geologia dell'Ambiente 2016, 2016/3, 14-19.

65. Carveni, P.; Capodicasa, A.; Iucolano, A. Peculiarità geomorfologiche e geoarcheologiche dell'area di Capo Passero (Sicilia sud-orientale). Geologia Dell Ambiente 2016, 2016/3, 55-61.

66. Amore, C.; D’Alessandro, L.; Giuffrida, E.; Giudice, A.; Zanini, A. Dinamica litorale tra Capo Peloro e Capo Passero (Sicilia orientale). Boll. Accad. Gioenia Sci. Nat. Ser. 1992, 25, 69-114.

67. Capodicasa, A. Il Forte di Capo Passero; Associazione Studi Storici e Culturali di Pachino: Pachino, Italy, $2007 ;$ p. 118.

68. Rivas-Martínez, S.; Penas, A.; Diaz, T.E. Bioclimatic Map of Europe-Bioclimates; University of Leon: Leon, Spain, 2004.

69. Rivas-Martínez, S.; De La Torre, M.W.; Del Arco, O.M.; De Paz Rodriguez, P.L.; Gallo, A.G.; Acebes, J.R.; Díaz, T.E.; Gonzales, F.F. Las comunidades vegetales de la Isla de Tenerife (Islas Canarias). Itinera Geobot. 1993, 7, 169-374.

70. Rivas-Martínez, S.; Saenz, S.R.; Peñas, A. Worlwide bioclimatic classification system. Glob. Geobot. 2011, 1, 1-634.

71. Bazan, G.; Marino, P.; Guarino, R.; Domina, G.; Schicchi, R. Bioclimatology and vegetation series in Sicily: A geostatistical approach. Ann. Bot. Fenn. 2015, 52, 1-18. [CrossRef]

72. Pignatti, S. Volume 1: Flora d'Italia \& Flora Digitale. In Flora d'Italia: In 4 Volumi, 2nd ed.; Edagricole-Edizioni Agricole di New Business Media srl: Milano, Italy, 2017.

73. Pignatti, S. Volume 2: Flora d'Italia \& Flora Digitale. In Flora d'Italia: In 4 Volumi, 2nd ed.; Edagricole-Edizioni Agricole di New Business Media srl: Milano, Italy, 2017.

74. Pignatti, S. Volume 3: Flora d'Italia \& Flora Digitale. In Flora d'Italia: In 4 Volumi, 2nd ed.; Edagricole-Edizioni Agricole di New Business Media srl: Milano, Italy, 2018.

75. Pignatti, S.; Guarino, R.; La Rosa, M. Volume 4: Flora d'Italia \& Flora Digitale. In Flora d'Italia: In 4 Volumi, 2nd ed.; EdagricoleEdizioni Agricole di New Business Media srl: Milano, Italy, 2019.

76. Fiori, A.; Paoletti, G. Flora Analitica d'Italia, Ossia Descrizione delle Piante Vascolari Indigene Inselvatichite e Largamente Coltivate in Italia Disposte per Quadri Analitici; Tipografia del Seminario: Padova, Italy, 1896-1908.

77. Fiori, A. Nuova Flora Analitica d'Italia; Tipografia M. Ricci: Firenze, Italy, 1923-1929.

78. Portal to the Flora of Italy. Available online: http:/dryades.units.it/floritaly (accessed on 28 October 2020).

79. R Development Core Team. R: A Language and Environment for Statistical Computing; R Foundation for Statistical Computing: Vienna, Austria, 2019.

80. Wickham, H. ggplot2: Elegant Graphics for Data Analysis; Springer: New York, NY, USA, 2016.

81. Braun-Blanquet, J. Pflanzensoziologie. Grundzüge der Vegetationskunde [Plant Sociology. Basic Course of Vegetation Science]; Springer: New York, NY, USA, 1964.

82. Van Der Maarel, E. Transformation of cover-abundance values in phytosociology and its effects on community similarity. Vegetatio 1979, 39, 97-114.

83. Mucina, L.; Bültmann, H.; Dierßen, K.; Theurillat, J.-P.; Raus, T.; Čarni, A.; Šumberová, K.; Willner, W.; Dengler, J.; García, R.G.; et al. Vegetation of Europe: Hierarchical floristic classification system of vascular plant, bryophyte, lichen, and algal communities. Appl. Veg. Sci. 2016, 19, 3-264. [CrossRef]

84. Biondi, E.; Blasi, C.; Burrascano, S.; Casavecchia, S.; Copiz, R.; Del Vico, E.; Galdenzi, D.; Gigante, D.; Lasen, C.; Spampinato, G.; et al. Manuale Italiano di Interpretazione degli habitat della Direttiva 92/43/CEE. Available online: http://vnr.unipg.it/habitat/ index.jsp (accessed on 9 February 2021).

85. Fois, M.; Podda, L.; Médail, F.; Bacchetta, G. Endemic and alien vascular plant diversity in the small Mediterranean islands of Sardinia: Drivers and implications for their conservation. Biol. Conserv. 2020, 244, 108519. [CrossRef]

86. Pirola, A. Isola di Capo Passero. In Censimento dei Biotopi di Rilevante Interesse Vegetazionale Meritevoli di Conservazione in Italia; Istituto di Botanica dell'Università: Camerino, Italy, 1971.

87. Blasi, C.; Marignani, M.; Copiz, R.; Fipaldini, M.; Bonacquisti, S.; Del Vico, E.; Rosati, L.; Zavattero, L. Important Plant Areas in Italy: From data to mapping. Biol. Conserv. 2010, 144, 220-226. [CrossRef]

88. Bernal-Casasola, D.; Maitana, D.; Mazzaglia, A.; Díaz, J.J. Atún y garum en las cetariae helenísticas y romanas de Portopalo y Vendicari (SR, Sicilia). Primeros apuntes interdisciplinares. HEROM 2020, (Suppl. 1).

89. Panitsa, M.; Trigas, P.; Kontakos, D.; Valli, A.-T.; Iatrou, G. Natural and cultural heritage interaction: Aspects of plant diversity in three East Peloponnesian castles (Greece) and conservation evaluation. Plant Biosyst. 2021. [CrossRef] 